$7-1-2018$

\title{
Hedge Fund vs. Non-Hedge Fund Institutional Demand and the Book-to-Market Effect
}

\author{
Mustafa Onur Caglayan \\ Umut Celiker \\ u.celiker@csuohio.edu
}

Gokhan Sonaer

Follow this and additional works at: https://engagedscholarship.csuohio.edu/bus_facpub

Part of the Finance and Financial Management Commons

How does access to this work benefit you? Let us know!

Publisher's Statement

NOTICE: this is the author's version of a work that was accepted for publication in the Journal of Banking and Finance. Changes resulting from the publishing process, such as peer review, editing, corrections, structural formatting, and other quality control mechanisms may not be reflected in this document. Changes may have been made to this work since it was submitted for publication. A definitive version was subsequently published in the Journal of Banking and FInance, 92, 07-01-2018; 10.1016/j.jbankfin.2018.04.021

\section{Recommended Citation}

Caglayan, Mustafa Onur; Celiker, Umut; and Sonaer, Gokhan, "Hedge Fund vs. Non-Hedge Fund Institutional Demand and the Book-to-Market Effect" (2018). Business Faculty Publications. 259. https://engagedscholarship.csuohio.edu/bus_facpub/259

This Article is brought to you for free and open access by the Monte Ahuja College of Business at EngagedScholarship@CSU. It has been accepted for inclusion in Business Faculty Publications by an authorized administrator of EngagedScholarship@CSU. For more information, please contact library.es@csuohio.edu. 


\title{
Hedge fund vs. non-hedge fund institutional demand and the book-to-market effect
}

\author{
Mustafa Onur Caglayan ${ }^{\mathrm{a}}$, Umut Celiker ${ }^{\mathrm{b}, *}$, Gokhan Sonaer $^{\mathrm{c}}$
}

\section{Introduction}

The book-to-market effect, the average return difference between high book-to-market and low book-to-market ratio securities, has been one of the oldest and most widely investigated topics in the asset pricing literature. Although Fama and French (1992, 1993, 1995, 1996) provide risk-based justifications, a large part of the following literature attributes this phenomenon to the naive investors' overreaction. Daniel et al. (1998), and Barberis et al. (1998) show investors' overconfidence, biased self-attribution and the tendency of investors to view events as representative to be the source of this overreaction. Similarly, La Porta et al. (1997) and more recently Brav et al. (2005) find significant evidence of expectations error, supporting the view of overreaction as the basis for the book-to-market premium. ${ }^{1}$

While naive investors' overreaction could contribute to the book-to-market effect, one can claim that sophisticated investors, namely, institutions, should exploit this return predictability, take advantage of the anomaly, and therefore mitigate the extent of overreaction. However, contrary to expectations, recent studies provide striking evidence that institutional investors actually exacerbate this price overreaction, thereby contributing to the bookto-market effect. In other words, institutions do not act in a sophisticated manner and do not take into account the information that high book-to-market (value) stocks outperform low book-tomarket (growth) stocks. Jiang (2010) shows empirical evidence that institutions tend to trade in the direction of intangible returns. ${ }^{2}$ In other words, institutions buy shares in response to positive intangible information and sell shares in response to negative intangible information, causing excessive pricing (overreaction) of such information, thereby contributing to the formation of book-to-anomaly, which is driven by the subsequent correction of overreaction to past high intangible returns. Jiang (2010) also reveals that the value effect increases with the intensity of institutional trading, particularly due to the poor subsequent performance of growth stocks that have been subject to intense uninformed institutional buying. 
In a recent study, Edelen et al. (2016) provide similar evidence that institutions not only fail to change their portfolios to take advantage of the book-to-market effect, but they do the opposite and buy significantly more of the overvalued low book-tomarket (growth) stocks compared to undervalued high book-tomarket (value) stocks over time. More importantly, Edelen et al. (2016) reveal a negative and significant relation between changes in institutional holdings and future stock returns when both the standard book-to-market anomaly portfolio formation period and the anomaly return measurement period span a year or longer. It is critical to emphasize that the underperformance of portfolios based on institutional trading with respect to book-to-market is driven primarily by the poor performance of growth stocks that are heavily bought by institutions.

In this paper, we examine whether a prominent sub-group of institutional investors, hedge funds, act differently than the other institutional investors and adjust their positions to take advantage of the book-to-market effect prior to the standard return measurement window of book-to-market portfolios. Our particular focus is on hedge funds; because both trading wise and structurally they differ from other institutional investors, such as mutual funds, pension funds, endowments, etc. in many ways. First, hedge funds have a much shorter horizon with their investments than other institutional investors. Compared to other institutional investors, hedge funds can get in and out of positions much easier and faster. This is evident in our data in the twice as high turnover statistics reported for hedge funds compared to other institutional investors. Second, hedge funds are not heavily regulated by government agencies and therefore they have much more flexibility in their investment strategies (including the use of short-sell, leverage and derivatives) and they do not face any concentration issues as do other institutions. Thus, when an opportunity comes up, hedge funds can either load on a particular stock heavily or short the stock as much as short-selling constraints allow, and in turn they can exhaust the mispricing to a great extent. ${ }^{3}$ In other words, hedge funds are in a better position to detect mispriced securities and trade them to their advantage compared to other institutional investors. ${ }^{4}$

We measure hedge fund and non-hedge fund demand (with respect to book-to-market effect) during the six-quarter window prior to return measurement of anomaly returns by utilizing the institutional demand measure of Edelen et al. (2016), which is based on the change in the number of institutions holding a stock in a given quarter. This measure, which primarily focuses on recently closed and opened positions in a stock, has a better ability to detect trades based on information, compared to changes in shares held in a stock by institutional investors, which may reflect trades based on operational needs such as fund flows and portfolio rebalancing. 5

Our results show that hedge funds indeed change their trading behavior with respect to low book-to-market (growth) and high book-to-market (value) stocks during April-June period (quarter $q$ ), after book-to-market values become public information during
January-March period (quarter $q-1$ ) of year $t .^{6}$ While the difference in the hedge fund demand between value and growth stocks during the prior five quarters from $q-5$ to $q-1$ (from January of year $t-1$ to March of year $t$ ) is significantly negative, it becomes significantly positive in quarter $q$ (April-June period of year $t$ ). ${ }^{7}$ Interestingly, we also document that non-hedge funds alter their trading preferences with respect to growth and value stocks in quarter $q$ compared to the previous five quarters, but not to the same degree as hedge funds do. ${ }^{8}$ We perceive this change in their trading direction in quarter $q$ as a signal that hedge funds start to pay attention to the value premium after the book-to-market values for the entire cross-section of stocks become available to sort firms into book-to-market portfolios.

The finding that hedge funds change their trading preferences with respect to growth and value stocks in quarter $q$ does not necessarily imply that they have superior ability to detect mispriced securities among growth and value stocks compared to other institutional investors. For a more direct test, we focus on the disagreement between hedge funds' and non-hedge funds' trading in quarter $q$ with respect to book-to-market effect, and examine whether such disagreement predicts the future stock returns. Our focus on disagreement is motivated by the fact that future abnormal returns of a stock that hedge funds buy (sell) cannot be attributed to hedge funds' superior stock picking ability if other types of institutions buy (sell) the same stock contemporaneously. To this end, we conduct independently sorted trivariate portfolio tests based on the book-to-market ratio as well as the trading direction of hedge funds and non-hedge funds simultaneously.

We find that hedge funds have better ability to detect mispriced growth stocks compared to non-hedge funds. ${ }^{9}$ In particular, growth stocks heavily bought by non-hedge funds and simultaneously sold by hedge funds in the most recent quarter $q$ (the April-June period), underperform significantly in the next year, generating statistically significant three- and four- factor alphas of $-1.21 \%$ and $-1.02 \%$ per month, respectively. Moreover, this result cannot be attributed to any price pressure, as the change in aggregate number of institutions as well as the change in the percentage of shares held by institutions for these aforementioned growth stocks are positive in quarter $q$. On the other hand, we do not find any significant negative subsequent abnormal returns for growth stocks heavily bought by hedge funds and simultaneously sold by nonhedge funds, indicating no evidence of an ability to detect overpriced growth stocks for non-hedge funds.

Looking at high book-to-market (value) stocks, we find somewhat weaker evidence of hedge funds detecting underpriced securities. That is, high book-to-market stocks heavily sold by nonhedge funds and simultaneously bought by hedge funds do not generate as statistically significant risk-adjusted returns (in abso- 
lute terms) in the following year as those observed in growth stocks. One plausible explanation for this difference in the results for overpriced vs. underpriced securities could be the asymmetry in arbitrage. The arbitrage of overpricing may take a long time due to short-selling constraints, whereas the arbitrage of underpricing is likely to be much easier as it only requires buying those underpriced securities. Due to this asymmetry in arbitrage, underpricing dissipates much faster than overpricing. ${ }^{10}$

In an effort to see what hedge funds capture in overpriced growth stocks, we examine and compare the characteristics of these stocks sold by- to the ones bought by hedge funds within the growth stocks heavily bought by non-hedge funds. Although there are some minor differences in the characteristics, including book-to-market ratios, size, price, demand, idiosyncratic volatility, illiquidity, intangible returns, and standardized earnings surprises across the two groups, controlling for these stock characteristics in multivariate Fama-MacBeth (1973) regressions does not eliminate the predictive power of hedge fund trading (demand) on the cross-sectional variation in future stock returns. This suggests that hedge funds are able to detect negative information about overpriced growth stocks better than other institutions, but this information is not confined to any specific stock characteristic that we consider.

This paper proceeds as follows: Section 2 provides a brief literature review. Section 3 provides information on data and variables and offers some summary statistics on hedge fund and non-hedge fund trading. Section 4 examines the change in trading preferences of hedge funds and non- hedge funds with respect to book-tomarket effect before and after book-to-market values become public information. Section 5 presents the return predictability tests conditional on the book-to-market ratio and the disagreement between hedge funds' and non-hedge funds' trades. Section 6 provides results from some robustness tests. Section 7 concludes the paper.

\section{Literature review}

The previous literature on institutional investors and their reaction to book-to-market effect reveals that institutions as a whole group tend to trade in the direction that exacerbates the value premium. Among the earlier studies, Frazzini and Lamont (2008) show that money tends to flow out of value-oriented mutual funds and into growth-oriented funds, inducing fund managers to sell value stocks and purchase growth stocks. They argue that value effect might be due to investor capital flowing into funds holding growth stocks. In a more specific context, examining the impact of institutional trading on book-to-market effect, Jiang (2010) reveals that the value effect increases with the intensity of institutional trading. More recently, Edelen et al. (2016) find evidence that institutions do not exploit the anomaly-predicted returns; and in fact, show that institutions buy growth stocks significantly more compared to value stocks, and those growth stocks heavily bought by institutions underperform in the subsequent periods. Different from the studies above, in this paper we focus on a sub-group of institu- tional investors, mainly hedge funds, and examine whether they trade differently from other institutions with respect to book-tomarket effect.

The explosive growth of hedge fund industry over the last two decades has yielded several studies on hedge funds' role in stock market efficiency. The findings from the previous literature provide good reasons to believe that hedge funds may act differently from non-hedge funds in the context of book-to-market effect. Among the ones closely related to our study, Akbas et al. (2015) show that flows to hedge funds reduce aggregate mispricing while aggregate flows to mutual funds exacerbate mispricing. In another recent study, Jiao and Ye (2014) examine the interaction between hedge fund and mutual fund herding, and find that mutual fund herding follows hedge fund herding, leading to a sharp price reversal in the following quarter; whereas hedge fund herding itself does not destabilize prices. Moreover, Cao et al. (2017) find evidence that hedge funds hold undervalued securities with large positive alphas, and show that hedge funds' holdings and trades are informative about the future stock returns. Similarly, Kokkonen and Suominen (2015) provide evidence that hedge funds' trades help reduce the undervaluation. In an earlier study, Brunnermeir and Nagel (2004), using holdings information of 53 hedge funds, show that hedge funds were able to trade in the right direction to a great extent both during formation and burst of the tech bubble. ${ }^{11}$ In this study, by using $13 \mathrm{~F}$ filings of hedge funds, we analyze the response of hedge funds to the book-to-market effect. Our study contributes to the literature by showing that hedge funds' trade direction changes after book-to-market values become public information.

Our study is also related to previous literature on hedge funds that analyzes the risk and peculiar characteristics of hedge funds that help them generate higher risk-adjusted returns compared to non-hedge funds. Joenvaara and Kahra (2017) provide a comprehensive summary on return-based and fund characteristicsbased predictors for future hedge fund performance. Titman and Tiu (2011) find that hedge funds with low R-squares on factors have higher Sharpe ratios. Sun et al. (2012) propose a measure of the distinctiveness of a fund's investment strategy (SDI) and find that higher SDI is associated with better subsequent performance. Bollen and Whaley (2009) and Patton and Ramadorai (2013) both document that hedge fund risk exposures are time-varying. ${ }^{12}$ In line with these studies, we find that hedge funds' exposure to high and low book-to-market stocks are time-varying as well. Moreover, we show that the growth stocks that are heavily bought by non-hedge funds and simultaneously sold by hedge funds experience significant losses in the following year, providing evidence that hedge funds have better ability to detect mispricing within the context of book-to-market anomaly. ${ }^{13}$ 


\section{Data, variable definitions, and summary statistics}

In this section, we describe the data and the construction of variables as well as provide a basic comparison between hedge funds and other institutions in regards to their trading behavior.

\subsection{Sample and data}

We obtain the data on stock prices and returns from the Center for Research in Security Prices (CRSP) Monthly Stock File. The accounting data are from CRSP/Compustat Merged Database. We include only US common stocks (CRSP share code of 10 or 11) traded on the NYSE, AMEX, and NASDAQ. We exclude stocks with negative book equity values. We eliminate stocks with share prices less than $\$ 5$ at the end of every June to alleviate the bid-ask bounce effect.

We define the book-to-market ratio of a firm in June of year $t$ by dividing the total book value of equity at the fiscal year end of a firm in year $t-1$ with total market value of equity at the end of calendar year $t-1$. The total book value of equity is measured by subtracting preferred stock value from the shareholder's equity. We use stockholder's equity (SEQ) to measure shareholder's equity. If stockholder's equity is missing, we use the sum of total common equity (CEQ) and preferred stock par value (PSTK). If shareholder's equity is still missing, we subtract total liabilities from total assets to measure the shareholder's equity. If any of these three ways do not yield any shareholder's equity measure, we treat it as missing for that firm in that year. For preferred stock value, we use redemption value (PSTKRV), liquidating value (PSTKL) and par value (PSTK) depending on availability in that order. If all three preferred stock values are missing, we treat book value of equity as missing. Finally, we add the balance sheet deferred taxes and investment credit (TXDITC) to the book value of equity, if they are not missing.

We obtain quarterly data on institutional holdings from the CDA/Spectrum database maintained by Thomson-Reuters. Institutions with greater than $\$ 100$ million under discretionary management are required to report their equity holdings to SEC if they have more than either 10,000 shares or $\$ 200,000$ in market value. We match hedge fund names obtained from Lipper Trading Advisor Selection System (TASS) database with the institution names in $13 \mathrm{~F}$ filings to generate the hedge fund holdings data. ${ }^{14,15}$ The holdings information in $13 \mathrm{~F}$ is filed at the advisory firm (manager) level rather than at the individual hedge fund level, and an advisor can advise multiple funds. We believe that the advisory firm level position openings and closings can better reflect the manager's information. Therefore, the advisory firm level data is appropriate for this study as we are interested in trading behavior of hedge fund managers with respect to the book-to-market effect. ${ }^{16}$
The institutional holdings data in Thomson-Reuters starts in December 1980 and we measure the institutional demand for the first time in the calendar quarter that ends in June of 1982 . The full period of our return tests span 384 months from July of 1982 to June of 2014.

\subsection{Summary statistics of hedge fund vs. non-hedge fund trading}

Table 1 shows descriptive statistics of institutional trading for hedge funds and non-hedge funds separately, where reported statistics are computed as the time-series averages of the crosssectional means and medians. The average number of hedge funds in our quarterly analysis is 196 , corresponding to $12.06 \%$ of the total number of institutional investors in our sample. This figure ranges from 44 in early years to 382 during the more recent period. Meanwhile, the average number of stocks in a hedge fund (non-hedge) portfolio is 314 (237). Following Carhart (1997), we compute the turnover of each institution by scaling the quarterly purchases or sales, whichever is smaller, to total assets. This methodology, using the minimum of sales or purchases, is able to detect fund trading mostly unrelated to the fund inflows or outflows. We find that turnover measures of hedge funds are on average $50 \%$ larger than that of other institutions. Additionally, we aggregate each fund's purchases and sales across stocks in a given quarter. For both buys and sells, we find that hedge funds' trades are almost twice as large in volume as those of other institutions. These are consistent with Griffin and $\mathrm{Xu}$ (2009) who find similar differences for hedge funds in terms of number of stocks, turnover, and size of long equity positions. Altogether, these patterns indicate that hedge funds' trades constitute an important portion of the stock market.

\section{Hedge fund vs. non-hedge fund demand based on book-to-market}

In this section, we explore how institutional investors, with a special focus on hedge funds, modify their portfolios over time with respect to the anomalous pattern in stock returns associated with the book-to-market ratio.

Jiang (2010) tracks changes in total institutional ownership during a four-quarter period from July of year $t-1$ to June of year $t$. Similarly, Edelen et al. (2016) analyze changes in institutional ownership during a six-quarter period from January of year $t-1$ to June of year $t$. These periods encompass the realization of bookto-market values over the year $t-1$, the announcement of book-tomarket values during the period from January to March of year $t$, and the three months following the full public disclosure of bookto-market values (the period from April to June of year $t$ ). Both Jiang (2010) and Edelen et al. (2016) analyze the implications of institutional demand for stock returns by measuring portfolio returns in the following year from the beginning of July of year $t$ to the end of June of year $t+1$ (i.e., the return measurement window of the anomaly returns).

Jiang (2010), Dasgupta et al. (2011), and Edelen et al. (2016) and papers on herding measures such as Wermers (1999) use the change in number of institutions to create measures of trading intensity. ${ }^{17}$ Similarly, we use the change in the number of institutions ( $\triangle \#$ inst) to measure the institutional demand for a stock in a given quarter. ${ }^{18}$ Following Chen, Hong and Stein (2002) and 
Table 1

Descriptive statistics of institutional trading: Hedge funds vs. Non-hedge funds

This table presents the summary statistics of the sample partitioned into two groups, namely, hedge funds and other institutions excluding hedge funds. Hedge funds in Thomson Reuter's $13 \mathrm{f}$ filings are determined by matching the names of hedge funds from the Lipper TASS dataset. Institutional holdings are derived using quarterly equity

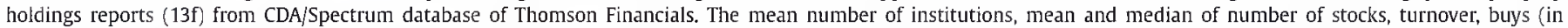

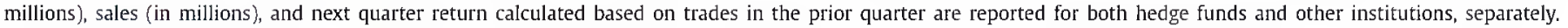

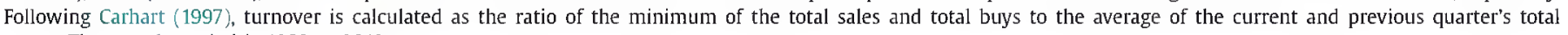
assets. The sample period is 1982 to 2013.

\begin{tabular}{|c|c|c|c|c|c|c|c|c|c|c|c|c|}
\hline \multirow[b]{2}{*}{ period } & \multirow[b]{2}{*}{ Type } & \multirow[b]{2}{*}{$\begin{array}{c}\text { No of } \\
\text { Institutions }\end{array}$} & \multicolumn{2}{|c|}{$\begin{array}{l}\text { No of stocks in } \\
\text { portfolio }\end{array}$} & \multicolumn{2}{|c|}{$\begin{array}{c}\text { Turnover } \\
\text { Min(Buys,Sales)/Assets }\end{array}$} & \multicolumn{2}{|c|}{ Buys (in millions) } & \multicolumn{2}{|c|}{ Sales (in millions) } & \multicolumn{2}{|c|}{$\begin{array}{l}\text { Next Quarter Return } \\
\text { based on trades }\end{array}$} \\
\hline & & & Mean & Median & Mean & Median & Mean & Median & Mean & Median & Mean & Median \\
\hline \multirow[t]{2}{*}{ 1982-1985 } & Non Hedge Fund & 567 & 189 & 121 & $9.39 \%$ & $7.11 \%$ & 98.03 & 34.88 & 92.06 & 32.25 & $0.28 \%$ & $0.41 \%$ \\
\hline & Hedge Fund & 44 & 259 & 158 & $12.59 \%$ & $10.85 \%$ & 203.26 & 90.98 & 183.04 & 73.94 & $0.86 \%$ & $1.05 \%$ \\
\hline \multirow[t]{2}{*}{$1986-1989$} & Non Hedge Fund & 759 & 220 & 122 & $10.73 \%$ & $7.97 \%$ & 131.96 & 40.75 & 130.61 & 41.49 & $0.20 \%$ & $0.28 \%$ \\
\hline & Hedge Fund & 69 & 290 & 173 & $13.92 \%$ & $12.52 \%$ & 284.72 & 134.43 & 287.65 & 129.27 & $0.53 \%$ & $0.69 \%$ \\
\hline \multirow[t]{2}{*}{$1990-1993$} & Non Hedge Fund & 899 & 235 & 114 & $9.42 \%$ & $6.75 \%$ & 147.99 & 35.89 & 131.23 & 34.47 & $0.14 \%$ & $0.14 \%$ \\
\hline & Hedge Fund & 95 & 288 & 150 & $14.17 \%$ & $11.95 \%$ & 290.03 & 121.72 & 258.36 & 119.98 & $0.38 \%$ & $0.50 \%$ \\
\hline \multirow[t]{2}{*}{ 1994-1997 } & Non Hedge Fund & 1082 & 264 & 113 & $10.62 \%$ & $7.69 \%$ & 258.74 & 44.37 & 230.71 & 42.05 & $0.20 \%$ & $0.22 \%$ \\
\hline & Hedge Fund & 130 & 359 & 148 & $17.51 \%$ & $14.32 \%$ & 537.14 & 175.56 & 477.39 & 151.97 & $0.48 \%$ & $0.38 \%$ \\
\hline \multirow[t]{2}{*}{$1998-2001$} & Non Hedge Fund & 1427 & 269 & 110 & $11.50 \%$ & $7,76 \%$ & 493.03 & 58.47 & 444.44 & 55.68 & $0.76 \%$ & $0.43 \%$ \\
\hline & Hedge Fund & 212 & 376 & 121 & $20.98 \%$ & $17.15 \%$ & 975.14 & 203.43 & 874.83 & 191.61 & $0.93 \%$ & $0.85 \%$ \\
\hline \multirow[t]{2}{*}{$2002-2005$} & Non Hedge Fund & 1733 & 256 & 95 & $11,67 \%$ & $6.96 \%$ & 333.13 & 39.78 & 301.51 & 37.76 & $0.22 \%$ & $0.22 \%$ \\
\hline & Hedge Fund & 284 & 336 & 105 & $22.59 \%$ & $18.33 \%$ & 654.95 & 163.99 & 600.91 & 138.72 & $0.57 \%$ & $0.54 \%$ \\
\hline \multirow[t]{2}{*}{$2006-2009$} & Non Hedge Fund & 2321 & 238 & 86 & $13.03 \%$ & $8.15 \%$ & 398.07 & 45.71 & 372.64 & 44.16 & $0.39 \%$ & $0.36 \%$ \\
\hline & Hedge Fund & 382 & 313 & 85 & $23.64 \%$ & $19.84 \%$ & 814.62 & 163.38 & 759.82 & 153.13 & $0.29 \%$ & $0.35 \%$ \\
\hline \multirow[t]{2}{*}{$2010-2013$} & Non Hedge Fund & 2647 & 222 & 79 & $12.29 \%$ & $7.35 \%$ & 316.36 & 38.70 & 311.70 & 39.09 & $-0.03 \%$ & $-0.04 \%$ \\
\hline & Hedge Fund & 351 & 293 & 80 & $21.23 \%$ & $16.85 \%$ & 689.96 & 144.70 & 671.66 & 143.08 & $-0.01 \%$ & $-0.01 \%$ \\
\hline \multirow[t]{2}{*}{$1982-2013$} & Non Hedge Fund & 1429 & 237 & 105 & $11.08 \%$ & $7.47 \%$ & 272.16 & 42.32 & 251.86 & 40.87 & $0.27 \%$ & $0.25 \%$ \\
\hline & Hedge Fund & 196 & 314 & 127 & $18.33 \%$ & $15.22 \%$ & 556.23 & 149.77 & 514.21 & 137.71 & $0.50 \%$ & $0.54 \%$ \\
\hline
\end{tabular}

Edelen et al. (2016), we also scale the change in the number of institutional investors in a given quarter by the average number of the same group institutional investors holding stocks in the same market capitalization decile based on NYSE breakpoints. ${ }^{19}$ In our study, we focus on hedge fund vs. non-hedge fund demand particularly in quarter $q$ (April-June period of year $t$ ) after the book-tomarket values become public information in quarter $q-1$, and analyze the implications of hedge fund and non-hedge fund demand on stock returns by looking at the next year portfolio returns in the same way as Jiang (2010) and Edelen et al. (2016). In Fig. 1, we provide a detailed picture of the timeline for measuring institutional demand and the following return measurement windw for our study as well as Jiang (2010) and Edelen et al. (2016).

In Table 2, we present evidence on how institutional demand varies over time and across stocks with different book-tomarket ratios while paying particular attention to hedge funds. Over the six quarters from January of year $t-1$ to June of year $t$ (i.e., from quarter $q-5$ to quarter $q$ in Table 2), institutional demand is greater for growth stocks than value stocks, consistent with Jiang (2010) and Edelen et al. (2016). We find that both hedge funds and non-hedge funds act similarly and invest more in growth stocks compared to value stocks during the same period.

Then, we divide the aforementioned six-quarter period into two sub-periods, and examine the institutional demand for the first five quarters (i.e., from quarter $q-5$ to quarter $q-1$ ), and for the last quarter $q$, just prior to the return measurement window, separately. We find for both hedge funds and non-hedge funds that the difference in average quarterly demand between value and growth stocks is negative and highly significant (in favor of growth stocks) in the first five quarters from quarter $q-5$ to $q-1$. Interestingly, we also notice for both hedge funds and non-hedge funds during the same time period that the difference in average quarterly demand between growth and neutral (quintile 3 ) stocks is significantly positive, while the difference in average quarterly demand between value and neutral stocks is significantly negative. In other words, both hedge fund and non-hedge fund demand decrease monotonically as we move from growth to value stocks during the period from $q-5$ to $q-1$.

In quarter $q$, however, hedge funds change their trading preferences drastically with respect to growth and value stocks. In this quarter, the difference in average quarterly hedge fund demand between value and growth stocks becomes positive and significant in favor of value stocks at $3.89 \%$ with a $t$-statistic of 3.63 . Similarly, the difference in average quarterly hedge fund demand between growth and neutral stocks also changes signs and becomes significantly negative in quarter $q$, while the difference in average quarterly hedge fund demand between value and neutral stocks changes signs and becomes significantly positive. ${ }^{20}$ That is, hedge fund demand this time increases monotonically as we move from growth to value stocks in quarter $q$. On the other hand, for nonhedge funds, in quarter $q$, although the difference in average quarterly demand between value and growth firms gets much smaller in magnitude, it remains still negative at $-0.84 \%$ and statistically significant at the $5 \%$ level in favor of growth stocks.

In panel A of Fig. 2, we plot the difference in average quarterly demand between value and growth stocks in each of the six quarters, $q-5$ to $q$ for hedge funds and non-hedge funds separately. This difference is negative in all of the first five quarters from $q-5$ to $q-1$ for both hedge funds and non-hedge funds, indicating a higher demand for growth stocks compared to value stocks. In quarter $q$, however, the demand difference flips sign only for 


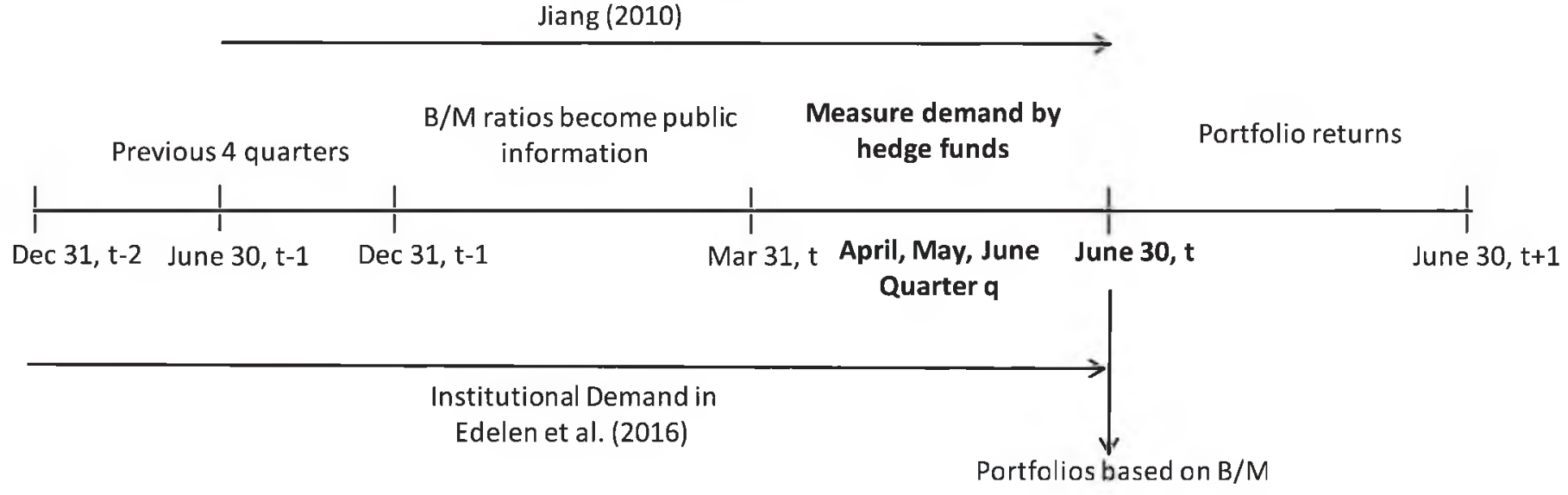

Fig. 1. Timeline for the construction of portfolios based on the book-to-market and institutional trading

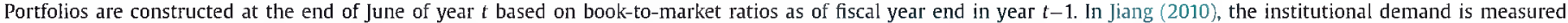

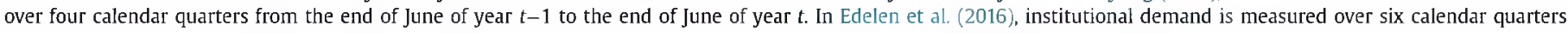

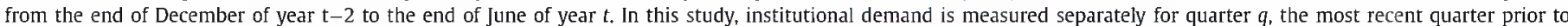

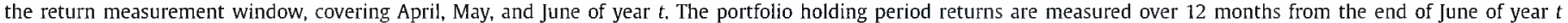
to the end of June of year $t+1$.

Table 2

Institutional demand over time for book-to-market quintiles

At the end of June of year $t$, five quintile portfolios are formed on the basis of book-to-market ratios measured based on the information at the end of December of year $t-1$. This table reports the average hedge fund demand, non-hedge fund demand, and total institutional demand for each book-to-market quintile for the quarter(s) $q-5$ to $q, q-5$ to $q-1$, and $q$, where $q$ is the quarter from the beginning of April of year $t$ to the end of June of year $t$. The difference in demand between high and low book-to-market quintiles, high and neutral book-to-market quintiles, low and neutral book-to-market quintiles are also presented. Heteroscedasticity and autocorrelation adjusted $t$-statistics are reported in parenthesis. Hedge fund (Non-hedge fund) demand for each stock is measured as the change in the number of hedge funds (non-hedge funds) holding the stock from the prior quarter scaled by the average number of hedge funds (non-hedge funds) holding stocks within the same market capitalization decile as of the March of year t. Similarly, institutional demand for each stock is measured as the change in the number of institutions holding the stock from the prior quarter scaled by the average number of institutions holding stocks within the same market capitalization decile as of the March of year $t$. All variables are winsorized at 1\% level. The sample period is from June 1982 to June 2013 . The numbers in bold denote significance at the $1 \%$ level.

\begin{tabular}{|c|c|c|c|c|c|c|c|c|c|}
\hline & \multicolumn{3}{|c|}{ Hedge fund demand } & \multicolumn{3}{|c|}{ Non-hedge fund demand } & \multicolumn{3}{|c|}{ Total institutional Demand } \\
\hline & {$[q-5, q]$} & {$[q-5, q-1]$} & $q($ April - June $)]$ & {$[q-5, q]$} & {$[q-5, q-1]$} & $q($ April - June $)]$ & {$[q-5, q]$} & {$[q-5, q-1]$} & $q$ (April-June) \\
\hline Growth (low B/M) & $9.22 \%$ & $9.97 \%$ & $4.40 \%$ & $8.30 \%$ & $8.66 \%$ & $4.92 \%$ & $8.42 \%$ & $8.86 \%$ & $4.82 \%$ \\
\hline 2 & $6.63 \%$ & $6.73 \%$ & $4.77 \%$ & $6.23 \%$ & $6.35 \%$ & $4.45 \%$ & $6.27 \%$ & $6.40 \%$ & $4.50 \%$ \\
\hline 3 (Neutral) & $5.50 \%$ & $4.94 \%$ & $6.15 \%$ & $4.41 \%$ & $4.28 \%$ & $4.08 \%$ & $4.55 \%$ & $4.38 \%$ & $4.41 \%$ \\
\hline 4 & $4.76 \%$ & $4.13 \%$ & $6.39 \%$ & $3.25 \%$ & $2.96 \%$ & $3.85 \%$ & $3.48 \%$ & $3.14 \%$ & $4.22 \%$ \\
\hline Value (high $\mathrm{B} / \mathrm{M}$ ) & $3.78 \%$ & $2.40 \%$ & $8.28 \%$ & $1.84 \%$ & $1.21 \%$ & $4.08 \%$ & $2.14 \%$ & $1.41 \%$ & $4.69 \%$ \\
\hline $\begin{array}{l}\text { Value - Growth } \\
\text { t-statistic }\end{array}$ & $\begin{array}{l}-5.45 \% \\
(-6.58)\end{array}$ & $\begin{array}{l}-7.58 \% \\
(-6.23)\end{array}$ & $\begin{array}{l}3.89 \% \\
(3.63)\end{array}$ & $\begin{array}{l}-6.46 \% \\
(-7.74)\end{array}$ & $\begin{array}{l}-7.45 \% \\
(-7.70)\end{array}$ & $\begin{array}{l}-0.84 \% \\
(-2.08)\end{array}$ & $\begin{array}{l}-6.28 \% \\
(-7.61)\end{array}$ & $\begin{array}{l}-7.45 \% \\
(-7.64)\end{array}$ & $\begin{array}{l}-0.13 \% \\
(-0.39)\end{array}$ \\
\hline $\begin{array}{l}\text { Growth - Neutral } \\
\text { t-statistic }\end{array}$ & $\begin{array}{l}3.73 \% \\
(6.78)\end{array}$ & $\begin{array}{l}5.04 \% \\
(6.16)\end{array}$ & $\begin{array}{l}-1.75 \% \\
(-3.12)\end{array}$ & $\begin{array}{l}3.89 \% \\
(6.50)\end{array}$ & $\begin{array}{l}4.38 \% \\
(6.76)\end{array}$ & $\begin{array}{l}0.84 \% \\
(1.92)\end{array}$ & $\begin{array}{l}3.87 \% \\
(6.61)\end{array}$ & $\begin{array}{l}4.48 \% \\
(6.81)\end{array}$ & $\begin{array}{l}0.41 \% \\
(1.04)\end{array}$ \\
\hline $\begin{array}{l}\text { Value - Neutral } \\
\text { t-statistic }\end{array}$ & $\begin{array}{l}-1.72 \% \\
(-5.16)\end{array}$ & $\begin{array}{l}-2.54 \% \\
(-5.80)\end{array}$ & $\begin{array}{r}2.14 \% \\
(2.92)\end{array}$ & $\begin{array}{l}-2.57 \% \\
(-8.75)\end{array}$ & $\begin{array}{l}-3.07 \% \\
(-8.64)\end{array}$ & $\begin{array}{l}-0.01 \% \\
(-0.02)\end{array}$ & $\begin{array}{l}-2.42 \% \\
(-8.19)\end{array}$ & $\begin{array}{l}-2.97 \% \\
(-8.41)\end{array}$ & $\begin{array}{l}0.28 \% \\
(1.00)\end{array}$ \\
\hline
\end{tabular}

hedge funds, indicating in fact a higher demand for value stocks compared to growth stocks by hedge funds. On the other hand, although the magnitude of the demand difference gets smaller, it still remains negative in quarter $q$ for non-hedge funds.

Panels $B$ and $C$ of Fig. 2 plot the differences in average quarterly demand between growth and neutral stocks, and between value and neutral stocks, respectively, for each six quarters, again for hedge funds and non-hedge funds separately. The relative demand (relative to neutral stocks) for growth stocks decreases after quarter $q-2$ for both hedge funds and non-hedge funds, but it switches from positive to negative in quarter $q$ only for hedge funds. As can be seen in panel C of Fig. 2, the trend in relative demand for value stocks over quarters $q-2$ to $q$ is similar, but in the opposite direction, with relative demand for value stocks switching from negative to positive only for hedge funds in quarter $q$.
These findings support our conjecture that hedge funds change their trading behavior with respect to growth and value stocks in quarter $q$, after book-to-market values become public information at the end of quarter $q-1$. Non-hedge funds also decrease (increase) their demand for growth (value) stocks in quarter $q$, but not to the same degree as hedge funds do.

\section{Return predictability}

\subsection{Book-to-market effect and disagreement between hedge funds and others}

After observing that both hedge funds and non-hedge funds in general change their trading in the same direction away from growth to value stocks in quarter $q$, in this section, we examine whether hedge funds or non-hedge funds are more capable of de- 
Panel A. Difference in Demand between value (V) and growth (G)

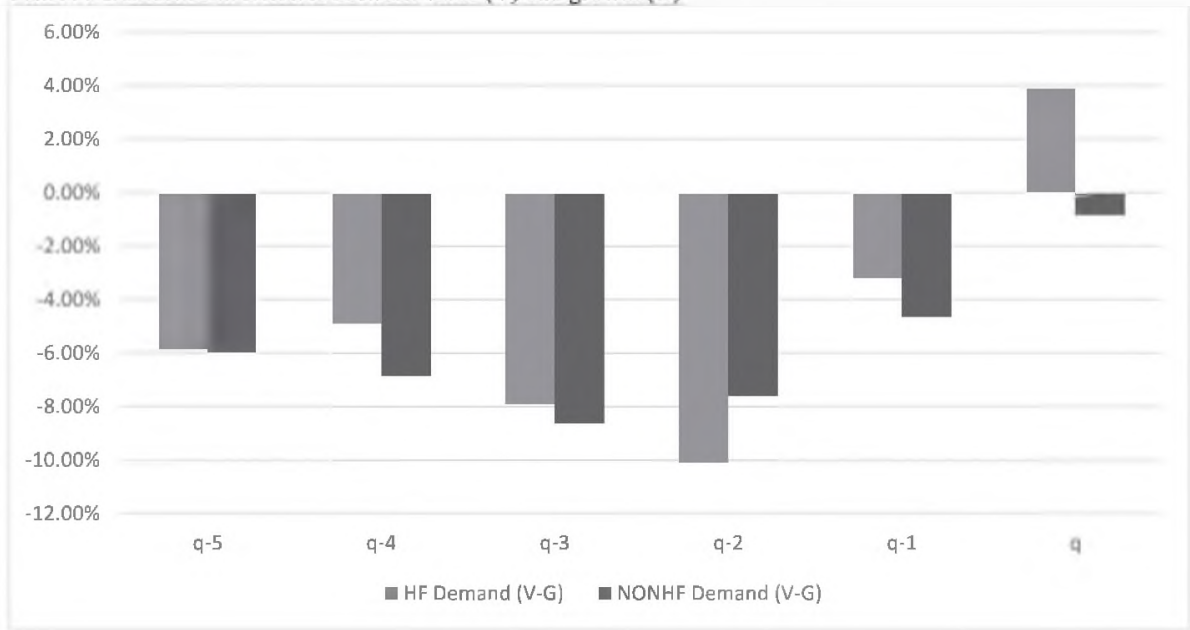

Panel B. Difference in Demand between growth $(\mathrm{G})$ and neutral $(\mathrm{N})$

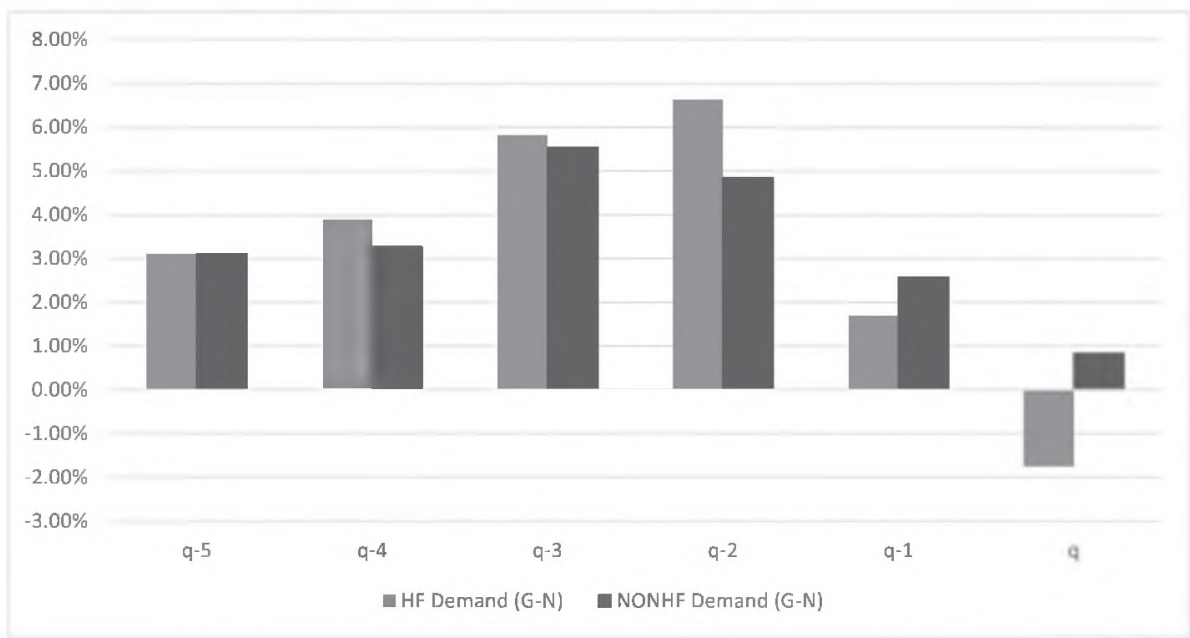

Panel C. Difference in Demand between value (V) and neutral (N)

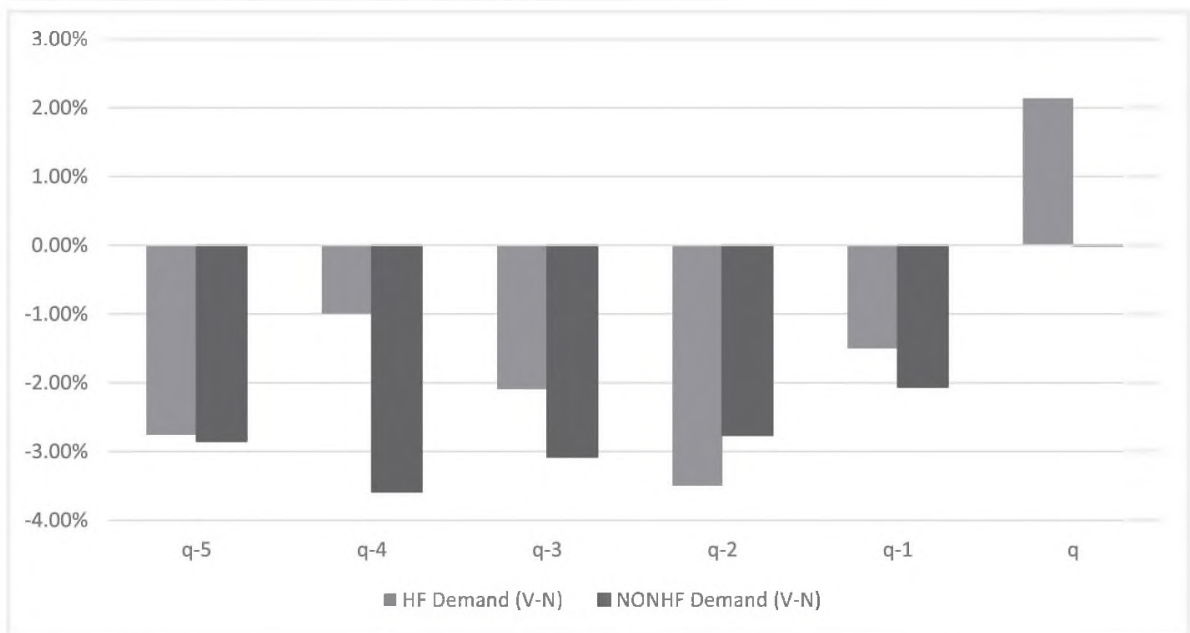

Fig. 2. Difference in demand between value and growth stocks over time for hedge funds and non-hedge funds

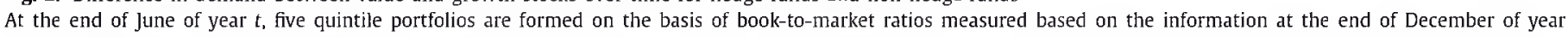

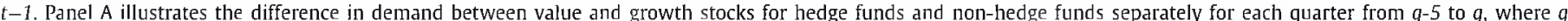

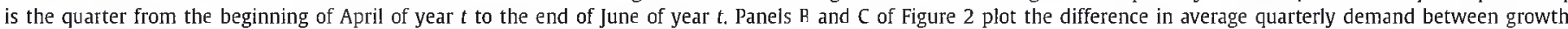

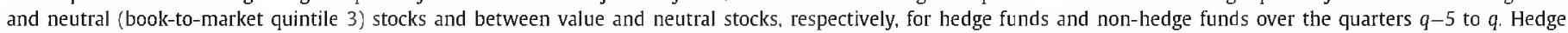

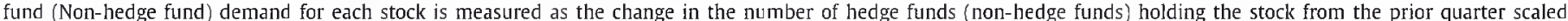

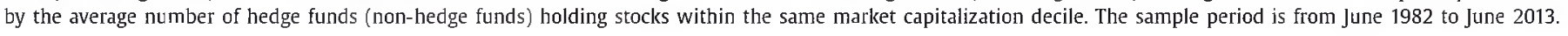


Table 3

Independently sorted portfolios based on institutional demand and book-to-market: Hedge funds vs. Non-hedge funds

At the end of June of year $t$, stocks are first independently sorted into quintiles based on the book-to-market ratios and the most recent quarter (quarter $q$ ) of nonhedge funds' trades. Then, within the top 20\% (heavy buy) and bottom 20\% (heavy sell) of non-hedge funds' trades, two sub-portfolios are created based on whether hedge funds buy or sell. For completeness of the analysis, the sorting procedure is also reversed, and this time stocks are independently sorted into quintiles based on the book-to-market ratios and the most recent quarter (quarter $q$ ) of hedge funds' trades. Then, within the top 20\% (heavy buy) and bottom $20 \%$ (heavy sell) of hedge funds' trades, two sub-portfolios are created based on whether non-hedge funds buy or sell. Portfolios are rebalanced at the end of June of each calendar year. For each sorting procedure, this table reports for the next one year (from July of year $t$ to the end of June $t+1$ ) the monthly CAPM alphas, Fama-French (1993) threefactor alphas, Carhart (1997) four-factor alphas and DGTW characteristic-adjusted returns for the four selected corner portfolios out of the 50 portfolios generated from the three-way independent sorting scheme. The sample period is July 1982 to June 2014. Heteroscedasticity and autocorrelation adjusted $t$-statistics are reported in parentheses. The numbers in bold denote significance at the $1 \%$ level.

\begin{tabular}{|c|c|c|c|c|c|c|}
\hline & \multicolumn{3}{|c|}{ NONHF heavy buy } & \multicolumn{3}{|c|}{ HF heavy buy } \\
\hline & HF sell & HF buy & B-S & NONHF sell & NONHF buy & B-S \\
\hline \# of stocks & 24 & 83 & & 29 & 97 & \\
\hline CAPM alpha & $-1.29 \%$ & $-0.41 \%$ & $0.88 \%$ & $-0.60 \%$ & $-0.50 \%$ & $0.10 \%$ \\
\hline t-stat & $(-5.03)$ & $(-1.85)$ & $(3.90)$ & $(-1,87)$ & $(-2.31)$ & $(0,38)$ \\
\hline 3-factor alpha & $-1.21 \%$ & $-0.20 \%$ & $1.01 \%$ & $-0.43 \%$ & $-0.30 \%$ & $0.13 \%$ \\
\hline t-stat & $(-5.53)$ & $(-1,21)$ & (3.96) & $(-1,68)$ & $(-2.21)$ & $(0,48)$ \\
\hline 4-factor alpha & $-1.02 \%$ & $-0.10 \%$ & 0.92\% & $-0.05 \%$ & $-0.16 \%$ & $-0.12 \%$ \\
\hline t-stat & $(-5.38)$ & $(-0.57)$ & (3.97) & $(-0.16)$ & $(-1.08)$ & $(-0.39)$ \\
\hline Char. Adj. Ret. & $-0.72 \%$ & 0.14 & 0.85 & $-0.09 \%$ & $-0.02 \%$ & $0.07 \%$ \\
\hline$t$-stat & $(-3.63)$ & $(0.91)$ & (3.72) & $(-0.39)$ & $(-0.13)$ & $(0.29)$ \\
\hline
\end{tabular}

Panel B. High book-to-market firms, Heavy Sell

\begin{tabular}{|c|c|c|c|c|c|c|}
\hline & \multicolumn{3}{|c|}{ NONHF heavy sell } & \multicolumn{3}{|c|}{ HF heavy sell } \\
\hline & HF sell & HF buy & B-S & NONHF sell & NONHF buy & $B-S$ \\
\hline \# of stocks & 44 & 44 & & 52 & 47 & \\
\hline CAPM alpha & $0.24 \%$ & $0.47 \%$ & $0.23 \%$ & $0.15 \%$ & $0.34 \%$ & $0.19 \%$ \\
\hline t-stat & $(0.95)$ & $(2.12)$ & $(1.40)$ & $(0.65)$ & $(1.51)$ & (1.39) \\
\hline 3-factor alpha & $-0.13 \%$ & $0.18 \%$ & $0.30 \%$ & $-0.20 \%$ & $0.00 \%$ & $0.20 \%$ \\
\hline t-stat & $(-0.85)$ & $(1.32)$ & $(1.85)$ & $(-1.52)$ & $(0.02)$ & $(1.40)$ \\
\hline 4-factor alpha & $0.18 \%$ & n.35\% & $0.17 \%$ & $0.06 \%$ & $0.13 \%$ & $0.06 \%$ \\
\hline t-stat & $(1.22)$ & (2.54) & $(1.04)$ & $(0.50)$ & $(0.97)$ & $(0.44)$ \\
\hline Char. Adj. Ret. & $0.02 \%$ & 0.04 & 0.02 & $-0.13 \%$ & $-0.10 \%$ & $0.03 \%$ \\
\hline$t$-stat & $(0.05)$ & $(0.31)$ & $(0.15)$ & $(-1.00)$ & $(-0.92)$ & $(0,22)$ \\
\hline
\end{tabular}

tecting mispriced securities in relation to book-to-market anomaly. This type of analysis, however, requires focusing on stocks for which different sets of investors disagree about the mispricing. For this purpose, we first independently sort stocks into quintiles based on the book-to-market ratios and the most recent quarter (quarter $q$ ) of non-hedge funds' demand. Then, within the top $20 \%$ (heavy buy) and bottom $20 \%$ (heavy sell) of non-hedge funds' demand for growth and value stocks, we further create two portfolios contemporaneously based on whether hedge funds' demand is positive (buy) or negative (sell). For completeness of the analysis, we also reverse the sorting procedure and independently sort stocks into quintiles based on the book-to-market ratios and the most recent quarter (quarter $q$ ) of hedge funds' demand. Then, within the top $20 \%$ (heavy buy) and bottom $20 \%$ (heavy sell) of hedge funds' demand for growth and value stocks, we further create two portfolios simultaneously based on whether non-hedge funds buy or sell. We rebalance these portfolios at the end of every June. The sample period for our return tests cover 384 months from July 1982 to June 2014. Table 3 reports the average number of stocks (within each portfolio) as well as the average monthly CAPM, three-factor, four-factor alphas and Daniel et al. (1997) (hereafter, DGTW) characteristic-adjusted returns along with heteroscedasticity-adjusted $t$-statistics of these al- ternative portfolios over the one-year return measurement window (from July of year $t$ to June of year $t+1$ ), where hedge fund and non-hedge fund trading (demand) agree and/or disagree in quarter $q^{21}$

Two striking results come to the surface out of this analysis. First, low book-to-market (growth) stocks heavily bought (high demand) by non-hedge funds and contemporaneously sold (low demand) by hedge funds in the most recent quarter significantly underperform in the following year those growth stocks heavily purchased by non-hedge funds and simultaneously bought by hedge funds. The CAPM, three-, four-factor alphas and characteristicadjusted returns of this underperformance are $0.88 \%(t$-stat $=3.90)$, $1.01 \%(t$-stat $=3.96), 0.92 \%(t$-stat $=3.97)$ and $0.85 \%(t$-stat $=3.72)$, respectively (see the B-S column on the left part of Panel A of Table 3). Second, the underperformance is completely driven by the poor performance of those stocks sold by hedge funds. The CAPM, three-, four-factor alphas and characteristic-adjusted returns of growth stocks heavily bought by non-hedge funds and simultaneously sold by hedge funds are $-1.29 \%(t$-stat $=-5.03),-1.21 \%(t-$ stat $=-5.53),-1.02 \%(t$-stat $=-5.38)$ and $-0.72 \%(t$-stat $=-3.63)$, respectively. ${ }^{22,23}$ On the other hand, within the sample of low book-to-market growth stocks heavily bought by hedge funds, there is no significant difference in subsequent abnormal performances between stocks sold and stocks bought by non-hedge funds (see the B-S column on the right part of Panel A of Table 3).

We also repeat our main analysis for a sample of hedge funds with equity-based strategies only, by excluding Fixed Income Arbitrage, CTAs, Managed Futures, and Emerging Market style funds from our sample. We find that the results from this new equitybased strategy only sample remain very similar to the results reported in Table $3 .{ }^{24}$ These findings altogether suggest that hedge funds have superior ability to detect the overpriced growth stocks compared to non-hedge funds. ${ }^{25}$ Notice also in Table 3 that among growth stocks heavily bought by non-hedge funds, the average number of stocks in the portfolio where hedge funds and nonhedge funds disagree (24) is much smaller compared to the number of stocks in the portfolio where they agree (83), suggesting that disagreement is much less common than agreement, and these rare instances of disagreement presents an opportunity to

\footnotetext{
21 The CAPM, three, and four-factor alphas are generated from the single factor CAPM, 3-factor model of Fama and French (1993), and 4-factor model of Fama and French (1993) and Carhart (1997), respectively. The characteristic- adjusted returns for each stock in each month is computed as the return difference between a stock and a portfolio of stocks that have comparable characteristics in terms of size, industry adjusted book-to-market value, and prior returns. For complete details, refer to Daniel et al. (1997).

22 Note that these results on low book-to-market stocks are not driven from the inclusion of the HML factor in the estimation of three- and four-factor alphas. Excluding the HML factor in estimation of the three- and four-factor alphas generate similar in magnitude negative and statistically significant alphas for those growth stocks heavily bought by non-hedge funds and simultaneously sold by hedge funds. ${ }^{23}$ It should be noted that this significant underperformance is not driven by outlier stock returns. When we exclude the most negative and the most positive returns within this portfolio each month, the monthly three- and four-factor alphas turn out to be $-1.38 \%$ and $-1.21 \%$, respectively, with the corresponding $t$-statistics of -6.25 and -6.36 .

${ }^{24}$ These results are not tabulated for the sake of brevity, but available upon request.

${ }^{25}$ Following Cao et al. (2017), we estimate for our portfolio of interest, the fourfactor alphas of individual securities by using daily returns in quarter $q$ - 1 . Specifically, we find the average of the four-factor daily alphas of growth stocks sold by hedge funds and bought by non-hedge funds to be $0.082 \%$ in quarter $q-1$. When we exclude the stocks with one-tail negative significant alphas from our analysis, we observe that the subsequent year portfolio returns for the portfolio of growth stocks sold by hedge funds and bought by non-hedge funds remain qualitatively unchanged from Table 3.
} 
test the relative ability of hedge funds to detect overpriced growth securities. ${ }^{26}$

On the other hand, a similar analysis for value stocks in Panel B of Table 3 shows that hedge funds' disagreement with non-hedge funds do not generate as significant abnormal returns (in absolute terms) as they do for growth stocks. Within high book-to-market value stocks heavily sold by non-hedge funds and contemporaneously bought by hedge funds, we observe a monthly CAPM and four-factor alpha of $0.47 \%(t$-stat $=2.12)$ and $0.35 \%(t$-stat $=2.54)$, respectively. However, the same figure turns out to be insignificant for the three-factor model and characteristic-adjusted returns, indicating a somewhat weaker evidence of hedge funds' ability to detect underpriced value securities. Lastly, in our analysis within the sample of high book-to-market value stocks heavily sold by hedge funds, we find no significant difference in subsequent abnormal performances between stocks sold and stocks bought by non-hedge funds (see the B-S column on the right part of Panel B of Table 3). ${ }^{27}$

In sum, we find evidence indicating that hedge funds have superior ability to detect overpriced growth stocks compared to nonhedge funds. However, we find no significant evidence of such ability when it comes to detecting underpriced value stocks. This difference in our findings, however, can be explained by the asymmetry in arbitrage. Due to short selling constraints, overpricing can persist for some time, while underpricing is likely to dissipate quickly as there are no constraints to buying stocks.

\subsection{Do stock characteristics explain what hedge funds capture?}

In the previous section, we show that hedge funds are better able to detect over-priced stocks with low book-to-market ratios. In this section, we attempt to understand if the differences in stock returns during the return measurement window are due to the behavior of the two types of institutions or simply due to differences in stock characteristics. In other words, we investigate if hedge funds are paying attention to some public information that non-hedge funds do not. For this purpose, we compare the characteristics of the stocks sold by hedge funds to the characteristics of stocks bought by hedge funds within the group of growth stocks heavily bought by non-hedge funds in quarter $q$.

We take into account a broad range of characteristics including hedge fund demand, non-hedge fund demand, and total institutional demand both in quarter $q$ and during quarters $q-5$ to $q-1$. We also compare for the portfolios of interest, the book-tomarket ratio, firm size, share price, illiquidity, idiosyncratic volatility, past one-year intangible return, momentum, and standardized earnings surprises (SUE). Lastly, we also evaluate raw and market-adjusted cumulative stock returns for the portfolios of interest for quarter $q$ and quarter $q-1$, separately. For illiquidity, we use Amihud (2002) stock illiquidity measure, which is de- fined as the ratio of the absolute return to the dollar trading volume averaged over the three months in quarter q. To measure idiosyncratic volatility, we use the standard deviation of residuals from the regressions of daily stock returns on Fama and French (1993) three factor model over the three months in quarter $q$. For intangible returns, we follow Daniel and Titman (2006), and estimate it as the residual of the annual cross-sectional regressions of log stock returns on the lagged log book-to-market ratio and past one-year book returns of stocks. Momentum is defined as the past 12 months' cumulative stock returns excluding the most recent month. Finally, for standardized earnings surprises (SUE), we follow Chordia and Shivakumar (2006), and compute SUE as $S U E_{i, q}=\left(E_{i q}-E_{i q}-4\right) / S \mathrm{Sd}_{i, q}$, where $E_{i q}$ is the earnings for firm $i$ in quarter $q$, and $\operatorname{std}_{i, q}$ is the standard deviation of the $\left(E_{i q}-E_{i, q}-4\right)$ over the prior eight quarters.

Table 4 presents the time-series averages of the mean, median, first and last quartiles of the characteristics of the portfolios of interest. First, among growth stocks heavily bought by non-hedge funds, we observe that stocks sold by hedge funds in quarter $q$ have a lower demand by non-hedge funds in the same quarter as well (30.32\% vs. $37.17 \%)$. Among growth stocks heavily bought by non-hedge funds and simultaneously sold by hedge funds, we also see that the total institutional demand in quarter $q$ is positive (16.34\%), suggesting that the consequent significant underperformance of these low book-to-market stocks cannot be explained by any price pressure. In addition, in Table 4 we also notice that for those stocks that are sold by hedge funds in quarter $q$, the institutional demand during the preceding five quarters (from $q-5$ to $q-1$ ) is noticeably stronger compared to those stocks bought by hedge funds ( $14.83 \%$ vs. $10.34 \%$ ). Interestingly, we observe a similar pattern in the preceding five quarters in both hedge fund demand $(26.31 \%$ vs. $12.25 \%)$ and non-hedge fund demand $(12.63 \%$ vs. $10.01 \%$ ). In other words, those growth stocks that are sold by hedge funds in quarter $q$ tend to be the stocks that have been subject to stronger institutional demand during the preceding five quarters.

Our results, however, do not reveal an outstanding difference in book-to-market ratio, firm size, share price, illiquidity and idiosyncratic volatility between stocks sold and stocks bought by hedge funds among the group of growth stocks heavily bought by nonhedge funds. It is worth noting that the average market capitalization of stocks sold by hedge funds is $\$ 726$ million, which is approximately equivalent to the third NYSE size decile. As small firms face greater short-selling constraints, this provides support for our explanation of overpricing of growth stocks for which hedge funds and non-hedge funds disagree. Lastly, for stocks sold by hedge funds, the Amihud (2002) illiquidity measure of 0.191 is almost half of the illiquidity measure of 0.351 averaged over all growth stocks. This further suggests that illiquidity does not seem to be a main driving force behind the significant underperformance of the portfolio of interest.

Lastly, we examine when the underperformance of these growth stocks sold by hedge funds begins. One possibility is that it begins while hedge funds trade during quarter $q$ or another possibility is that the underperformance begins during quarter $q-1$ (January to March). These scenarios may cast doubt on our interpretation that hedge funds correctly identify which growth stocks will underperform. Table 4 shows, however, no evidence for such an earlier underperformance. In fact, for those growth stocks sold by hedge funds, the portfolio return in excess of the market return is positive and its magnitude is $3.38 \%$ and $5.62 \%$ during the quarters $q$ and $q-1$, respectively. Furthermore, in quarter $q$ where we measure institutional demand, stocks sold by hedge funds have still a positive average earnings surprise $(0.77)$. These results suggest that the growth stocks sold by hedge funds in quarter $q$, were not already underperforming during quarters $q$ or $q-1$, and there were no signs of negative earnings surprises either. We also find 
Table 4

Characteristics of stocks bought vs. stocks sold by hedge funds among growth stocks heavily bought by Non-hedge funds in quarter $q$

The table reports the time-series averages of the mean, median, first, and last quartiles of stock characteristics for the portfolios of stocks sold and stocks bought by hedge funds within the sample of growth stocks heavily bought by nonhedge funds. At the end of June of year $t$, stocks are first independently sorted into quintiles based on the book-to-market ratios and the most recent quarter (quarter q) of non-hedge funds' trades. Then, within the top 20\% (heavy buy) of nonhedge funds' trades of growth (low book-to-market) stocks, two sub-portfolios are created based on whether hedge funds buy or sell. Portfolios are rebalanced at the end of June of each calendar year. Hedge fund (Non-hedge fund) demand for each stock is measured as the change in the number of hedge funds (non-hedge funds) holding the stock from the prior quarter scaled by the average number of hedge funds (non-hedge funds) holding stocks within the same market capitalization decile. Similarly, institutional demand for each stock is measured as the change in the number of institutions holding the stock from the prior quarter scaled by the average number of institutions holding stocks within the same market capitalization decile. Illiquidity is the average ratio of the daily absolute return to the dollar trading volume in quarter $q$. Idiosyncratic volatility is the standard deviation of residuals of the regression of daily stock returns on Fama and French (1993) three factor model over the three months in quarter $q$. Return ( $q$ ) and Return $(q-1)$ are the cumulative stock returns over the quarters $q$ and $q-1$, respectively. Similarly, Excess Return $(q)$ and Excess Return $(q-1)$ are the cumulative stock returns in excess of the market return over the quarters $q$ and $q-1$, respectively. The intangible return is the residual from the regression of the past one-year log returns on the lagged book-to-market ratio and book returns as in Daniel and Titman (2006). Momentum measures the past 12 months' cumulative returns from July of year $t-1$ to June of year $t$. SUE (q) is computed as the earnings surprise in quarter $q$ scaled by the standard deviation of the earnings surprises over the prior eight quarters. The earnings surprise in quarter $q$ is measured as the difference between quarter $q$ earnings and quarter $q-4$ earnings. The sample period is 1982 to 2013.

\begin{tabular}{|c|c|c|c|c|c|c|c|c|}
\hline & \multicolumn{2}{|c|}{ Mean } & \multicolumn{2}{|c|}{ Median } & \multicolumn{2}{|c|}{ Q1 } & \multicolumn{2}{|c|}{ Q3 } \\
\hline & HF sell & HF Buy & HF sell & HF Buy & HF sell & HF Buy & HF sell & HF Buy \\
\hline$\Delta \#$ \#inst. $(q)$ & $16.34 \%$ & $41.02 \%$ & $13.72 \%$ & $32.83 \%$ & $8.59 \%$ & $23.47 \%$ & $21.34 \%$ & $55.39 \%$ \\
\hline$\triangle \# \operatorname{HF}(q)$ & $-55.32 \%$ & $66.69 \%$ & $-44.53 \%$ & $49.33 \%$ & $-88.32 \%$ & $26.93 \%$ & $-21.65 \%$ & $97.23 \%$ \\
\hline$\triangle \# \operatorname{NHF}(q)$ & $30.32 \%$ & $37.17 \%$ & $25.34 \%$ & $29.35 \%$ & $18.88 \%$ & $20.46 \%$ & $35.17 \%$ & $48.63 \%$ \\
\hline Avg. $\Delta \#$ inst. $(q-5, q-1)$ & $14.83 \%$ & $10.34 \%$ & $12.34 \%$ & $8.68 \%$ & $5.50 \%$ & $3.16 \%$ & $21.50 \%$ & $16.42 \%$ \\
\hline Avg. $\triangle \# \mathrm{HF}(q-5, q-1)$ & $26.31 \%$ & $12.25 \%$ & $22.66 \%$ & $9.03 \%$ & $7.78 \%$ & $1.42 \%$ & $42.11 \%$ & $21.48 \%$ \\
\hline Avg. $\triangle \#$ NHF $(q-5, q-1)$ & $12.63 \%$ & $10.01 \%$ & $10.31 \%$ & $8.35 \%$ & $3.97 \%$ & $3.02 \%$ & $19.49 \%$ & $15.61 \%$ \\
\hline $\mathrm{B} / \mathrm{M}$ & 0.197 & 0.191 & 0.208 & 0.199 & 0.143 & 0.133 & 0.255 & 0.252 \\
\hline Size (in millions) & 726.42 & 1094.58 & 312.91 & 374.71 & 165.10 & 182.90 & 776.45 & 904.16 \\
\hline Price & 21.18 & 24.71 & 17.19 & 20.24 & 10.53 & 12.35 & 28.47 & 32.58 \\
\hline Ivol & 0.031 & 0.031 & 0.030 & 0.029 & 0.023 & 0.023 & 0.038 & 0.037 \\
\hline Il]iquidity & 0.191 & 0.174 & 0.048 & 0.036 & 0.019 & 0.011 & 0.176 & 0.128 \\
\hline Intangible return & $44.72 \%$ & $46.32 \%$ & $43.12 \%$ & $45.90 \%$ & $16.27 \%$ & $17.99 \%$ & $75.36 \%$ & $75.25 \%$ \\
\hline Momentum & $48.66 \%$ & $76.68 \%$ & $33.34 \%$ & $58.67 \%$ & $-1.01 \%$ & $20.31 \%$ & $81.14 \%$ & $118.41 \%$ \\
\hline $\operatorname{Return}(q)$ & $6.69 \%$ & $19.77 \%$ & $5.89 \%$ & $16.65 \%$ & $-9.80 \%$ & $1.10 \%$ & $20.65 \%$ & $34.62 \%$ \\
\hline Return $(q-1)$ & $9.57 \%$ & $15.48 \%$ & $6.07 \%$ & $11.75 \%$ & $-9.74 \%$ & $-3.96 \%$ & $24.75 \%$ & $30.23 \%$ \\
\hline Excess Return $(q)$ & $3.38 \%$ & $16.13 \%$ & $2.39 \%$ & $13.11 \%$ & $-12.70 \%$ & $-2.06 \%$ & $16.82 \%$ & $30.80 \%$ \\
\hline Excess Return $(q-1)$ & $5.62 \%$ & $11.34 \%$ & $2.23 \%$ & $7.57 \%$ & $-13.18 \%$ & $-7.66 \%$ & $20.41 \%$ & $25.46 \%$ \\
\hline $\operatorname{SUE}(q)$ & 0.77 & 0.97 & 0.60 & 0.70 & -0.17 & 0.07 & 1.61 & 1.89 \\
\hline
\end{tabular}

no difference in intangible returns between stocks sold and stocks bought by hedge funds within the sample of stocks heavily bought by non-hedge funds ( $44.72 \%$ vs. $46.32 \%)$. Lastly, we find the momentum (past 12 months' cumulative performance excluding the most recent month) to be somewhat lower for the stocks sold by hedge funds ( $48.66 \%$ vs. $76.68 \%$ ), the only category where there seems to be a difference between stocks sold and stocks bought by hedge funds. ${ }^{28}$

We next employ multivariate Fama-MacBeth cross-sectional regressions of monthly stock returns on previous quarters' institutional demand as well as stock characteristics in quarter $q$, to see if the above mentioned differences undermine the role of hedge funds' superior ability to detect overpriced growth stocks. To explain the monthly individual stock returns in the cross-section, we use the same aforementioned variables, including hedge fund and non-hedge fund demand in quarter $q$, total institutional demand during the preceding five quarters from quarters $q-5$ to $q-1$, the natural logarithm of firm size at the end of June of year $t$, the natural logarithm of the book-to-market ratio at the end of December of year $t-1$, past 12 month's cumulative performance excluding the most recent month, illiquidity, idiosyncratic volatility, the intangible return, and the standardized unexpected earnings at the end of June of year $t$. In Table 5, we run three alternative regression specifications for low book-to-market growth stocks heavily bought by non-hedge funds. The sample period is July 1982 to June 2014, covering 384 months. Note that we winsorize all independent variables at the $1 \%$ level, and control for heteroscedasticity and serial correlations in all of our analyses.

Table 5 reports the average slope coefficients along with $t$ statistics and $\mathrm{p}$-values from the monthly cross-sectional regressions (from July of year $t$ to June of year $t+1$ ) of future stock returns on hedge fund and non-hedge fund demand in quarter $q$ with and without control variables. The findings from FamaMacBeth cross-sectional regressions confirm our key finding that hedge funds' trading (demand) positively predicts the future returns of growth stocks that are heavily bought by non-hedge funds. In the first model where only hedge fund and non-hedge fund demand are used as explanatory variables, the slope coefficients on hedge fund and non-hedge fund demand are 0.006 with a $t$ statistic of 2.35 and -0.004 with a $t$-statistic of -0.74 , respectively. In the second model, we add total institutional demand during the preceding five quarters from quarters $q-5$ to $q-1$ to the regression 
Table 5

Fama-MacBeth regressions of future stock returns on institutional demand and stock characteristics within the sample of growth stocks heavily bought by non-hedge funds

Within the sample of growth stocks heavily purchased by non-hedge funds, this table reports average coefficient estimates along with their t-statistics (in parenthesis) and p-values from the monthly cross-sectional regressions (from July of year $t$ through June of $t+1$ ) of future stock returns on hedge fund and non-hedge fund demand in quarter $q$ and control variables. Hedge fund (Non-hedge fund) demand in quarter $q$ for each stock is measured as the change in the number of hedge funds (non-hedge funds) holding the stock from the prior quarter scaled by the average number of hedge funds (non-hedge funds) holding stocks at the end of $q-1$ within the same market capitalization decile. Similarly, institutional demand from $q-5$ to $q-1$ for each stock is measured as the change in the number of institutions holding the stock from $q-5$ to $q-1$ scaled by the average number of institutions holding stocks at the end of $q-5$ within the same market capitalization decile. The control variables for stock characteristics include (1) natural log of book-to-market ratio, (2) natural log of firm size, (3) prior 12 months' cumulative returns (momentum), (4) Illiquidity, (5) Idiosyncratic volatility, (6) SUE measured in quarter $q$, and (7) intangible return. All independent variables are calculated as described in Table 4 as of June end of year t. All independent variables are winsorized at $1 \%$ level. Standard errors are corrected for serial correlation and heteroscedasticity. The sample period is July 1982 to June 2014. The numbers in bold denote significance at the $1 \%$ level.

\begin{tabular}{cccccc}
\hline & Intercept & $\Delta$ \#HF $(q)$ & $\Delta$ \#NHF $(q)$ & $\Delta$ \#inst. $(q-5, q-1)$ & Stock Characteristics \\
\hline \multirow{3}{*}{ Model 1 } & 0.007 & $\mathbf{n . n n 6}$ & -0.004 & & \multirow{2}{*}{ No } \\
& $(1.75)$ & $\mathbf{( 2 . 3 5 )}$ & $(-0.74)$ & & \\
& 0.081 & 0.019 & 0.460 & & No \\
Model 2 & 0.008 & $\mathbf{0 . 0 n 6}$ & -0.004 & -0.002 & \\
& $(2.11)$ & $\mathbf{( 2 . 3 9 )}$ & $(-0.72)$ & $(-1.49)$ & Yes \\
& 0.035 & 0.018 & 0.472 & 0.136 & \\
\hline
\end{tabular}

model as well, and find that the coefficient on hedge fund demand is still 0.006 with a $t$-statistic of 2.39 , indicating that controlling for the effect of institutional demand during the preceding five quarters does not eradicate the predictive power of quarter $q$ hedge fund demand on future stock returns. Lastly, in the third model, we add all stock characteristics, including book-to-market, firm size, momentum, illiquidity, idiosyncratic volatility, and SUE into our regression model, and still find a statistically significant relation between hedge fund demand and subsequent returns; an average slope coefficient of 0.006 with a $t$-statistic of 2.85 on hedge fund demand. ${ }^{29}$

To sum up, the findings from the cross-sectional regression analyses confirm our portfolio test results and suggest that hedge funds' superior ability to detect overpriced growth stocks is not driven by other firm characteristics such as size, illiquidity, idiosyncratic volatility, SUE and past returns.

\subsection{The role of disagreement in the full cross-section of stock returns}

The results from the portfolio level analysis show that the disagreement between hedge funds and other institutions in quarter $q$ play a major role in predicting the future underperformance of growth stocks. More specifically, growth stocks heavily bought by other institutions and simultaneously sold by hedge funds in quarter $q$ underperform significantly in the following period. In this section, using the full cross-section of stock returns, we test for the existence of a possible asymmetry of such negative underperformance in relation to the growth stocks and institutional demand over the preceding five quarters from $q-5$ to $q-1$.

Table 6 presents results from a set of Fama-MacBeth regressions of future monthly stock returns on the disagreement between hedge funds and other institutions, past institutional demand, and stock characteristics. We first create a Disagreement dummy variable that is observed at the end of June of year $t$ (quarter $q$ ) and takes the value of 1 when a stock is heavily bought by non-hedge funds (i.e., top $20 \%$ of non-hedge fund demand) and sold by hedge funds in quarter $q$, and 0 otherwise. We next create a Growth dummy variable that takes the value of 1 if a stock is in the lowest book-to-market quintile in quarter $q$, and 0 otherwise. Our measure of institutional demand from $q-5$ to $q-1, \Delta$ inst $(q-5$, $q-1$ ), is the scaled change in the number of institutions for a stock over the five quarters from $q-5$ to $q-1$. We also create a High Institutional Demand dummy variable that takes the value of 1 if a stock is in the top $\Delta \operatorname{inst}(q-5, q-1)$ quintile in quarter $q$, and 0 otherwise. We include in the regression models the interaction terms of the dummy variables to capture any asymmetries as well. Lastly, in all of the cross-sectional regressions, we include control variables including, the natural log of firm size, the natural log of book-tomarket ratio, the return over the past one year excluding the most recent month ending in May of year $t$, the illiquidity measure, the idiosyncratic volatility, the standardized earnings surprises, and the intangible return. ${ }^{30}$ The independent variables are updated at the end of June of year $t$. Thus, they are the same for 12 monthly regressions from July of year $t$ to June of year $t+1$. Coefficient estimates in Table 6 are time-series averages of monthly coefficients, and $t$-statistics are based on Newey-West (1987) standard errors using six-lags.

Model 1 in Table 6 examines the predictive power of the disagreement between hedge funds and non-hedge funds across all stocks controlling for the stock characteristics. The overall relation between disagreement and future returns is negative and statistically significant, with an average coefficient of -0.0019 on the Disagreement dummy and a $t$-statistic of -2.36 . Model 2 examines if this negative relation is symmetric across growth vs. other stocks, by including the interaction of Disagreement dummy with Growth dummy in the regression equation. Notably, the coefficient 


\section{Table 6}

Fama-MacBeth regressions of future stock returns on the disagreement in quarter $q$, long term institutional demand and stock characteristics

This table reports average coefficient estimates along with their $t$-statistics (in parenthesis) and p-values from the monthly cross-sectional regressions (from July of year $t$ through June of $t+1$ ) of future stock returns on the disagreement dummy in quarter $q$, preceding five quarter institutional demand $\Delta$ inst ( $q-5$, $q-1$ ), and stock characteristics. The disagreement dummy takes the value of 1 when a stock is heavily bought by non-hedge funds (i.e., top $20 \%$ of nonhedge fund demand) and sold by hedge funds in quarter $q$, and 0 otherwise. The disagreement dummy variable's interactions with growth stocks and high institutional demand are also controlled in regression specifications $2-4$. Growth dummy is generated such that it takes the value of 1 if a stock is in the lowest book-to-market quintile in quarter $q$, and 0 otherwise. High Institutional Demand dummy is created such that it takes the value of 1 if a stock is in the top $\Delta$ inst $(q-5, q-1)$ quintile in quarter $q$, and 0 otherwise. The control variables for stock characteristics include (1) natural log of book-to-market ratio, (2) natural $\log$ of firm size, (3) prior 12 months' cumulative returns (momentum), (4) Illiquidity, (5) Idiosyncratic volatility, (6) SUE measured in quarter $q$, and (7) intangible return. All independent variables are calculated as described in Table 4 as of June end of year $t$. All continuous independent variables are winsorized at $1 \%$ level. Standard errors are corrected for serial correlation and heteroscedasticity. The sample period is July 1982 to June 2014 . The numbers in bold denote significance at the $1 \%$ level.

\begin{tabular}{|c|c|c|c|c|c|c|}
\hline Model & Intercept & Disagreement & Disagreement $\times$ Growth & Disagreement $\times$ High Inst. Demand $(q-5, q-1)$ & $\Delta$ inst. $(q-5, q-1)$ & Characteristics \\
\hline & 0.0154 & -0.0019 & & & & \\
\hline \multirow[t]{3}{*}{1} & $(4,71)$ & $(-2.36)$ & & & & Yes \\
\hline & $<0.001$ & 0.019 & & & & \\
\hline & 0.0154 & -0.0006 & -0.0065 & & & \\
\hline \multirow[t]{3}{*}{2} & $(4.70)$ & $(-0.63)$ & $(-3.18)$ & & & Yes \\
\hline & $<0.001$ & 0.526 & 0.002 & & & \\
\hline & 0.0156 & 0.0002 & & -n.nกfin & -0.0018 & \\
\hline \multirow{2}{*}{3} & $<0.001$ & 0.816 & & $<0.001$ & 0.001 & \\
\hline & 0.0156 & 0.0010 & - & -0.0054 & -0.0018 & \\
\hline \multirow[t]{2}{*}{4} & $(4.86)$ & $(1.06)$ & $(-2.39)$ & $(-3.17)$ & $(-3.26)$ & Yes \\
\hline & $<0.001$ & 0.290 & 0.017 & 0.002 & 0.001 & \\
\hline
\end{tabular}

on the Disagreement dummy drops to zero and becomes statistically insignificant, while the interaction term (Disagreement dummy $\mathrm{x}$ Growth dummy) captures the negative predictive power of the disagreement with an average coefficient of -0.0065 and a $t$-statistic of -3.18 . This asymmetry suggests that the predictive ability of the disagreement between hedge funds and other institutions in quarter $q$ is limited to growth stocks.

In Model 3, we next include institutional demand over the preceding five quarters, $\Delta$ inst $(q-5, q-1)$, and the interaction between Disagreement dummy and High Institutional Demand dummy in the regression equation. We find a significant and negative relation between institutional demand, $\Delta \operatorname{inst}(q-5, q-1)$, and future returns, which is consistent with prior studies (e.g., Jiang (2010), Dasgupta et al. (2011), and Edelen et al. (2016)) which document a negative relation between institutional investors' past long term trading and future stock returns. Furthermore, we find the interaction term (Disagreement dummy x High Institutional Demand dummy) has a larger average coefficient of -0.0060 with a $t$-statistic of -3.58 . This finding suggests that the negative predictive power of disagreement is also confined to those stocks which have been subject to high level of institutional demand in the past.

Lastly, Model 4 includes interactions of Disagreement dummy with Growth dummy and Disagreement dummy with High Institutional Demand dummy simultaneously. The results show that the disagreement-growth relation is robust to the control of past institutional demand. The coefficient on the interaction term (Disagreement dummy $\mathrm{x}$ Growth dummy) is -0.0050 with a $t$-statistic of -2.39 . Hence, any correlation between disagreement in quarter $q$ and past institutional demand over $q-5$ to $q-1$ does not explain the future underperformance of growth stocks which are heavily bought by non-hedge funds and simultaneously sold by hedge funds in quarter $q$.

Taken in their entirety, the results in this section show that the negative relation between disagreement in quarter $q$ and future returns is confined to growth stocks and to those stocks invested heavily by institutions over the preceding five quarters from $q-5$ to $q-1{ }^{31}$ However, these two effects do not subsume each other.

\section{Robustness check}

\subsection{Quarterly returns}

Prior literature provide evidence that the ability of institutional trades predicting future returns depend on the horizons over which both trading and returns are measured. ${ }^{32}$ Edelen et al. (2016) provide evidence that institutions trading in quarter $q$ based on the anomalies (e.g., buy minus sell portfolios within growth and value stocks) generates positive alphas confined only to next two quarters following the portfolio formation, which is consistent with the price pressure effect rather than the institutional investors' ability to pick stocks. We examine whether the significant subsequent year underperformance of growth stocks heavily bought by non-hedge funds and simultaneously sold by hedge funds is driven by the poor performance in a specific quarter.

Table 7 documents the average monthly CAPM, three-, fourfactor alphas and DGTW characteristic-adjusted returns for the portfolios of interest for each of the four quarters. We find the next one-year underperformance of low book-to-market stocks heavily bought by non-hedge funds and contemporaneously sold by hedge funds in quarter $q$ is not confined to a specific quarter. The weakest negative alphas are in $q+2$, where the monthly threeand four-factor alphas are $-1.05 \%(t$-stat $=-2.02)$ and $-0.79 \%(t-$ stat $=-1.95$ ), respectively, while the strongest alphas are in $q+4$ where three- and four-factor alphas are $-1.30 \%$ ( $t$-stat $=-3.21$ ) and $-1.23 \%$ ( $t$-stat $=-3.39$ ), respectively. ${ }^{33}$ Thus, the results from Table 7 show that hedge fund's detection of over-priced stocks in quarter $q$ and those stocks' significant underperformance in the 
Table 7

Future quarterly returns of growth stocks heavily bought by non-hedge funds in quarter $q$

Stocks are first independently sorted into quintiles based on the book-to-market ratios and the most recent quarter (quarter $q$ ) of non-hedge funds' trades. Then, within the top 20\% (heavy buy) of nonhedge funds' trades of growth (low book-to-market) stocks in quarter $q$, two sub-portfolios are created based on whether hedge funds buy or sell. Portfolios are rebalanced at the end of June of each calendar year. The table reports for each of the next four calendar quarters (from July of year $t$ to the end of June $t+1$ ) the monthly CAPM alphas, Fama-French (1993) three-factor alphas, Carhart (1997) four-factor alphas and DGTW (1997) characteristic-adjusted returns of the two aforementioned sub-portfolios in question. The sample period is July 1982 to June 2014. Heteroscedasticity and autocorrelation adjusted $t$-statistics are reported in parentheses. The numbers in bold denote significance at the $5 \%$ level or better.

\begin{tabular}{|c|c|c|c|}
\hline \multirow[b]{2}{*}{ Qtr } & & \multicolumn{2}{|c|}{ NONHF heavy buy } \\
\hline & & HF sell $(<0)$ & HF buy $(>0)$ \\
\hline \multirow{9}{*}{$q+1$ (July, August, September) } & CAPM alpha & $-1.71 \%$ & $-0.02 \%$ \\
\hline & t-stat & $(-3.90)$ & $(-0.04)$ \\
\hline & 3-factor alpha & $-1.35 \%$ & $0.54 \%$ \\
\hline & t-stat & $(-3.66)$ & $(1.87)$ \\
\hline & 4-factor alpha & $-1.09 \%$ & $0.68 \%$ \\
\hline & t-stat & $(-2.84)$ & (2.20) \\
\hline & Char. Adj. Ret. & $-0.95 \%$ & $0.45 \%$ \\
\hline & t-stat & $(-2.87)$ & $(1.43)$ \\
\hline & CAPM alpha & $-1.33 \%$ & $-0.52 \%$ \\
\hline \multirow{7}{*}{$q+2$ (October, November, December) } & t-stat & $(-2.26)$ & $(-1.06)$ \\
\hline & 3-factor alpha & $-1.05 \%$ & $-0.22 \%$ \\
\hline & t-stat & $(-2.02)$ & $(-0.70)$ \\
\hline & 4-factor alpha & $-0.79 \%$ & $-0.08 \%$ \\
\hline & t-stat & $(-1.95)$ & $(-0.26)$ \\
\hline & Char Adj. Ret. & $-0.42 \%$ & 0.33 \\
\hline & t-stat & $(-1.99)$ & $(1.10)$ \\
\hline \multirow{9}{*}{$q+3$ (January, February, March) } & CAPM alpha & $-0.84 \%$ & $-0.76 \%$ \\
\hline & t-stat & $(-1.64)$ & $(-1.84)$ \\
\hline & 3-factor alpha & $-1.12 \%$ & $-0.83 \%$ \\
\hline & t-stat & $(-2.81)$ & $(-2.69)$ \\
\hline & 4-factor alpha & $-0.96 \%$ & $-0.75 \%$ \\
\hline & t-stat & $(-2.57)$ & $(-2.33)$ \\
\hline & Char. Adj. Ret. & -0.63 & -0.29 \\
\hline & t-stat & $(-1.97)$ & $(-1.08)$ \\
\hline & CAPM alpha & $-1.25 \%$ & $-0.35 \%$ \\
\hline \multirow{7}{*}{$q+4$ (April, May, June) } & t-stat & $(-2.61)$ & $(-0.81)$ \\
\hline & 3-factor alpha & $-1.30 \%$ & $-0.31 \%$ \\
\hline & t-stat & $(-3.21)$ & $(-1.09)$ \\
\hline & 4-factor alpha & $-1.23 \%$ & $-0.28 \%$ \\
\hline & t-stat & $(-3.39)$ & $(-1.03)$ \\
\hline & Char. Adj. Ret. & $-0.8 \mathrm{R} \%$ & $0.06 \%$ \\
\hline & t-stat & $(-2.37)$ & $(0.20)$ \\
\hline
\end{tabular}

subsequent year is not due to a large underperformance in a specific quarter. That is, the underperformance persists in all four quarters, suggesting that hedge fund demand (within the universe of growth stocks heavily bought by non-hedge funds) is a robust indicator of future quarterly returns as well.

The quarterly return analysis reported in Table 7 also reveals an interesting trading strategy based on the disagreement between hedge funds and other institutions with respect to the book-tomarket effect. Specifically, we suggest an enhanced book-to-market return spread by taking short positions in growth stocks sold by hedge funds and heavily bought by other institutions, and by taking long positions in value stocks sold heavily by other institutions and bought by hedge funds. Such a strategy, skipping the first three months after the end of June of year $t$ (i.e., the standard portfolio formation calendar month in the relevant literature), can be formed at the end of September of year $t$ after observing the quarter $q$ trades of institutions during the $q+1$ period. This zerocost investment portfolio strategy held over a nine-month period yields an average monthly three-factor alpha of $1.39 \%$ (1.18\% (short side) $+0.22 \%$ (long side) ). ${ }^{34}$

\subsection{Sub-period analysis}

The Lipper TASS starts including defunct funds in the database starting from 1994. Therefore, we may be missing from our analyses some hedge funds that have shut down before 1994. The existence of survivorship bias in the TASS database prior to 1994 may have an effect on our full sample results. In addition, bookto-market's recognition as an anomaly starting with Fama and French (1992), might have reduced the magnitude of the anomaly in following years, moderating the size of the abnormal returns that can be generated on those growth stocks heavily bought by non-hedge funds and simultaneously sold by hedge funds. In order to address these potential concerns, we examine whether the full sample results vary over time. To this end, we divide our full sample period July 1982 to June 2014 covering 384 months into two sample periods; July 1982 to June 1995, and July 1995 to June 2014. We report the average monthly CAPM, three-factor, four-factor alphas, and DGTW characteristic-adjusted returns of portfolios of interest along with their $t$-statistics in these two sub-periods in Table 8. 


\section{Table 8}

Sub-period analysis of growth stocks heavily bought by non-hedge funds

Stocks are first independently sorted into quintiles based on the book-to-market ratios and the most recent quarter (quarter $q$ ) of non-hedge funds' trades. Then, within the top 20\% (heavy buy) of non-hedge funds' trades of growth (low book-to-market) stocks, two sub-portfolios are created based on whether hedge funds buy or sell. The portfolio return measurement window is from July of year $t$ to June of year $t+1$. Portfolios are rebalanced at the end of June of each calendar year. For each sub-sample period, the table reports for the next one year (from July of year $t$ to the end of June $t+1$ ) the monthly CAPM alphas, Fama-French (1993) three-factor alphas, Carhart (1997) four-factor alphas and DGTW (1997) characteristic-adjusted returns of the two aforementioned sub-portfolios in question. The two subsample periods are July 1982 to June 1995, and July 1995 to June 2014. Heteroscedasticity and autocorrelation adjusted $t$-statistics are reported in parentheses. The numbers in bold denote significance at the $1 \%$ level.

\begin{tabular}{|c|c|c|c|c|c|c|}
\hline & \multicolumn{3}{|c|}{ July 1982 to June 1995} & \multicolumn{3}{|c|}{ July 1995 to June 2014} \\
\hline & HF sell $(<0)$ & HF buy $(>0)$ & Buy-Sell & HF sell $(<0)$ & HF buy $(>0)$ & Buy-Sell \\
\hline CAPM alpha & $-1.42 \%$ & $-0.63 \%$ & $0.79 \%$ & $-1.18 \%$ & $-0.26 \%$ & $0.92 \%$ \\
\hline t-stat & $(-3.78)$ & $(-1.93)$ & (2.51) & $(-3.32)$ & $(-0.88)$ & (2.82) \\
\hline 3-factor alpha & $-0.98 \%$ & $-0.13 \%$ & $0.85 \%$ & $-1.23 \%$ & $-0.21 \%$ & $1.02 \%$ \\
\hline t-stat & $(-3.77)$ & $(-0.47)$ & $(2.62)$ & $(-3.98)$ & $(-1.03)$ & $(2.81)$ \\
\hline 4-factor aipha & $-1.02 \%$ & $-0.18 \%$ & $0.84 \%$ & $-1.02 \%$ & $-0.08 \%$ & $0.94 \%$ \\
\hline t-stat & $(-3.86)$ & $(-0,63)$ & (2.35) & $(-4.13)$ & $(-0.37)$ & (2.90) \\
\hline Char. Adj. Ret & $-0.58 \%$ & $0.19 \%$ & $0.77 \%$ & $-0.81 \%$ & 0.10 & 0.91 \\
\hline$t$-stat & $(-2.45)$ & $(0.77)$ & (2.49) & $(-3.15)$ & $(0.53)$ & (3.21) \\
\hline
\end{tabular}

The results presented in Table 8 confirm the existence and continuation of a significant underperformance of growth stocks heavily bought by non-hedge funds and contemporaneously sold by hedge funds in the more recent survivorship bias free period (July 1995 to June 2014) as well. The low book-to-market stocks heavily bought by non-hedge funds and sold by hedge funds yield a monthly three-factor alpha of $-0.98 \%$ ( $t$-stat $=-3.77$ ) for the earlier sub-sample period and a monthly three-factor alpha of $-1.23 \%$ $(t$-stat $=-3.98)$ for the more recent sub-sample period. The results are similar for the four-factor alphas and DGTW characteristicadjusted returns as well.

In sum, our main results from the full sample period hold for both of the sub-periods, suggesting that our findings are robust and are not driven by the survivorship bias that exists in the hedge fund database prior to $1994 .{ }^{35}$

\subsection{The effect of small number of stocks on portfolio returns}

In our analyses most of the return predictability tests are conducted on the subset of growth stocks that are heavily bought by non-hedge funds. Among these stocks, the significant results are generated from a subset of stocks that are sold by hedge funds (24 stocks on average as reported in Table 3 ). The small number of stocks in the portfolio of interest may raise concerns about the generalizability of our findings. To that end, we examine the timeseries variation in portfolio size (i.e., the number of stocks in the portfolio) for portfolios of growth stocks heavily bought by nonhedge funds and simultaneously sold by hedge funds. In Fig. 3, we illustrate a histogram of the number of stocks in the portfolio of interest covering the full sample period of 384 months. While the average numbers of stocks in our portfolio of interest is 24 , the minimum number of stocks goes down below 10 to only 9 only once. More importantly, in 300 out of the 384 months (i.e., 78\% of the time), the portfolio of interest has more than 15 stocks at a given point in time. We next check the effect of small number of stocks (in the portfolio of interest) on our main findings. We find that when the months with portfolios with less than 20 stocks are excluded from the analysis, the monthly CAPM, threefactor, four-factor alphas, and DGTW characteristic-adjusted returns of the growth stocks heavily bought by non-hedge funds and sold by hedge funds turn out to be $-0.98 \%$ ( $t$-stat $=-3.27),-0.98 \%(t-$ stat $=-3.83),-0.90 \%(t$-stat $=-3.64)$, and $-0.66 \%(t$-stat $=-3.02)$, respectively. This shows that the extreme small number of stocks does not have any significant impact on our main findings.

In order to further address the issue and ease concerns about the effect of small number of stocks on our main findings, we repeat our trivariate portfolio analysis by expanding the number of stocks in our portfolio of interest. To this end, each year we sort the stocks based on the previous fiscal year-end book-to-market ratios and identify the top 30 percentile (value) and the bottom 30 percentile (growth) stocks. We also sort stocks independently based on their quarter $q$ non-hedge fund demand and identify the top 30 percentile (heavy buy) and bottom 30 percentile (heavy sell) stocks. Then, within the top $30 \%$ (heavy buy) and bottom $30 \%$ (heavy sell) of non-hedge funds' demand for value and growth stocks, we further create two portfolios contemporaneously based on whether hedge funds' demand is positive (buy) or negative (sell). Generating trivariate portfolios in this format by focusing on the top and bottom 30\% (as opposed to 20\%) of book-to-market ratios and non-hedge fund demand increases the average number of stocks in the portfolio of interest to 63 from 24. We next compute the average monthly CAPM, three-factor, four-factor alphas, and DGTW characteristic adjusted returns of these alternative portfolios (with larger number of stocks) over the one-year return measurement window.

Similar to our results reported in Panel A of Table 3, growth stocks heavily bought by non-hedge funds and contemporaneously sold by hedge funds significantly underperform in the following year those growth stocks heavily purchased by non-hedge funds and simultaneously bought by hedge funds. The CAPM, threefactor, four-factor alphas, and DGTW characteristic-adjusted returns of this underperformance are $0.31 \%(t$-stat $=2.41), 0.42 \%(t-$ stat $=3.18), 0.34 \%(t$-stat $=2.85)$, and $0.43 \%(t$-stat $=2.89)$, respectively. More importantly, this underperformance is mainly due to the poor performance of those stocks sold by hedge funds. The CAPM, three-factor, four-factor alphas, and DGTW characteristicadjusted returns of growth stocks heavily bought by non-hedge funds and simultaneously sold by hedge funds are $-0.62 \%$ ( $t$ stat $=-3.25),-0.56 \%(t$-stat $=-4.09),-0.41 \%(t$-stat $=-3.20)$, and $-0.38 \%$ ( $t$-stat $=-3.01)$, respectively, when the average number of stocks in the portfolio is 63 , much higher than the original 24 


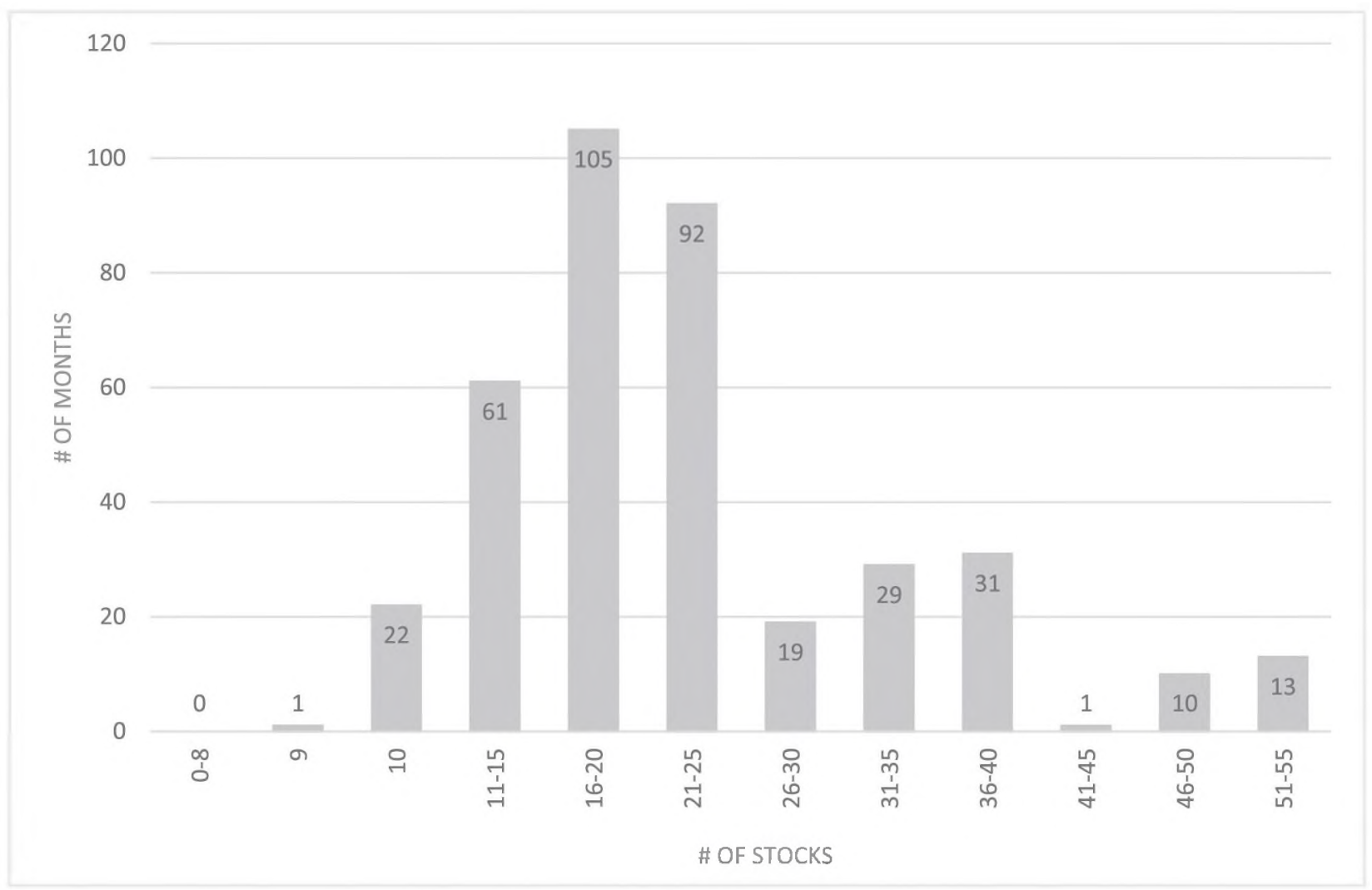

Fig. 3. Histogram of the number of growth stocks heavily bought by non-hedge funds and simultaneously sold by hedge funds in quarter $q$

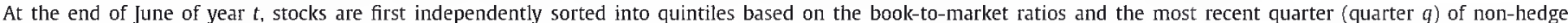

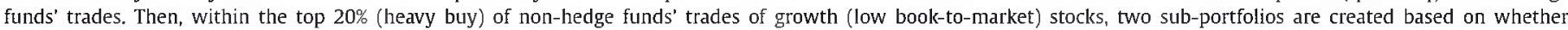

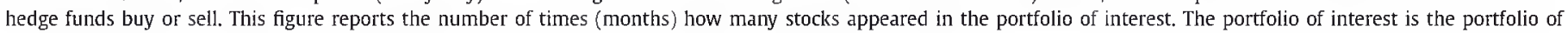
growth stocks heavily bought by non-hedge funds and simultaneously sold by hedge funds in quarter $q$.

stocks in the portfolio. ${ }^{36}$ Therefore, our inferences regarding the superior ability of hedge funds in detecting overpriced growth stocks remain the same even when we expand the number of stocks in our portfolio of interest.

Finally, one last related possible concern might be the effect of extreme outliers on the large negative alphas when the number of stocks in the portfolio of interest is low. As an additional robustness check, each month we exclude from our original trivariate portfolios the stocks with the minimum and maximum monthly returns. When these two stocks are excluded from our analyses, the monthly CAPM, three-factor, four-factor alphas, and DGTW characteristic-adjusted returns of the growth stocks heavily bought by non-hedge funds and sold by hedge funds become $-1.46 \%$, $-1.38 \%,-1.21 \%$, and $-0.93 \%$, respectively, and still statistically significant at the $1 \%$ level, again showing no significant change from the full sample results. All in all, we can conclude that the small number of stocks in our portfolio of interest does not seem to have any significant impact on our main findings.

\section{Conclusion}

Recent studies find that institutional investors' actions as a whole group exacerbate the price overreaction, contributing to the book-to-market effect (see, e.g., Jiang, 2010 and Edelen et al., 2016). We examine whether a prominent sub-group of institutional investors, i.e., hedge funds, act in the same manner as most other institutions, and fail to take advantage of the arbitrage opportunities generated by the value premium. We find that hedge funds change their preference from growth stocks to value stocks in the quarter immediately after the book-to-market values of all stocks become public information. However, the finding that hedge funds change their trading preferences with respect to growth and value stocks does not necessarily mean that they have superior ability to detect mispriced securities among growth and value stocks compared to other institutional investors. For a more direct test, we focus on the disagreement between hedge funds' and non-hedge funds' trading with respect to book-to-market effect, and examine whether such disagreement predicts the future stock returns. We find evidence suggesting that hedge funds can detect overpriced growth securities when there is a major difference in opinions with non-hedge funds, who aggressively move in the opposite direction.

We believe our findings that hedge funds alter their trading in favor of value stocks in the quarter immediately after book-tomarket values become public information as well as the fact that hedge funds have the ability to detect overpriced growth securities complement the literature and open the venue for future research on the role of disagreements between market participants to better understand other stock return anomalies.

\section{References}

Agarwal, V., Jiang, W., Tang, Y., Yang, B., 2013. Uncovering hedge fund skill from the portfolio holdings they hide. J. Finance $68,739-783$.

Agarwal, V., Naik, N.Y., 2000. Multi-period performance persistence analysis of hedge funds. J. Financ, Quant. Anal. 35, 327-342.

Agarwal, V., Naik, N.Y., 2004. Risks and portfolio decisions involving hedge funds. Rev. Financ. Stud. 17, 63-98.

Akbas, F., Armstrong, W.J., Sorescu, S., Subrahmanyam, A., 2015. Smart money, dumb money, and capital market anomalies. J. Financ. Econ. 118, 355-382. 
Ali, A., Hwang, L.S., Trombley, M.A., 2003. Arbitrage risk and the book-to-market mispricing. J. Financ. Econ. 69, 355-373.

Amihud, Y., 2002. Illiquidity and stock returns: cross-section and time-series effects. J. Financ. Markets 5, 31-56.

Asquith, P., Pathak, P.A., Ritter, J.R., 2005. Short interest, institutional ownership, and stock returns. ]. Financ. Econ. 78, 243-276.

Bali, T.G., Brown, S.J., Caglayan, M.O., 2011. Do hedge funds' exposures to risk factors predict their future returns? J. Financ. Econ. 101, 36-68.

Bali, T,G., Brown, S.J., Caglayan, M.O., 2012. Systematic risk and the cross-section of hedge fund returns. J. Financ. Econ. 106, 114-131.

Bali, T.G., Brown, S.J., Caglayan, M.O., 2014. Macroeconomic risk and hedge fund returns. J. Financ. Econ, 114, 1-19.

Barberis, N., Shleifer, A., Vishny, R., 1998. A model of investor sentiment. J. Financ. Econ. 49, 307-343.

Bennett, J.A., Sias, R., Starks, L.T., 2003. Greener pastures and the impact of dynamic institutional preferences. Rev. Financ. Stud. 16, 1203-1238.

Bollen, N.P.B., Whaley, R.E., 2009. Hedge fund risk dynamics: implications for performance appraisal. J. Finance 64, 985-1035.

Brav, A., Lehavy, R., Michaely, R., 2005. Using expectations to test asset pricing models. Financ. Manag. 34, 31-64.

Brown, S.J., Schwartz, C., 2013 Working paper. Do market participants care about portfolio disclosure? Evidence from hedge funds' $13 \mathrm{f}$ filings.

Brunnermeier, M.K., Nagel, S., 2004. Hedge funds and the technology bubble. J. Finance $59,2013-2040$.

Calluzzo, P., Moneta, F., Topaloglu, S., 2016. When Anomalies are Publicized Broadly, Do Institutions Trade Accordingly? Working paper.

Cao, C., Chen, Y., Goetzmann, W.N., Liang, B., 2017. The Role of Hedge Funds in the Security Price Formation Process Working paper.

Cao, C., Chen, Y., Liang, B., Lo, A.W., 2013. Can hedge funds time market liquidity? J. Financ. Econ. 109, 493-516.

Carhart, M.M., 1997. On persistence in mutual fund performance. J. Finance 52, $57-82$.

Chen, H., Jegadeesh, N., Wermers, R., 2000. The value of active mutual fund management: an examination of the stockholdings and trades of fund managers. J. Financ. Quant. Anal. 35, 343-368.

Chen, J., Hong, H., Stein. J.C., 2002. Breadth of ownership and stock returns. J. Financ. Econ. $66,171-205$.

Chen, Y, Liang, B., 2007. Do market timing hedge funds time the market? J. Financ. Quant. Anal. 42, 827-856.

Chordia, T., Shivakumar, L., 2006. Earnings and price momentum. J. Financ. Econ. 80 $627-656$.

D'avolio, G., 2002. The market for borrowing stock. J. Financ. Econ. 66, 271-306

Daniel, K., Grinblatt, M., Titman, S., Wermers, R., 1997. Measuring mutual fund performance with characteristic-based benchmarks. J. Finance 52, 1035-1058

Daniel, K., Hirshleifer, D., Subrahmanyam, A., 1998. Investor psychology and security market under- and overreactions. J. Finance 53, 1839-1886.

Daniel, K., Titman, S., 2006. Market reactions to tangible and intangible information. J. Finance $61,1605-1643$

Dasgupta, A., Prat, A., Verardo, M., 2011. Institutional trade persistence and long-term equity returns. J. Finance 66, 635-653.

Diether, K., Malloy, C., Scherbina, A., 2002. Differences of opinion and the cross section of stock returns. J. Finance 57, 2113-2141.

Edelen, R.M., Ince, O.S., Kadlec, G.B., 2016. Institutional investors and stock market anomalies. J. Financ. Econ. 119, 472-488.

Edwards, F.R., Caglayan, M.O., 2001. Hedge fund performance and manager skill. J Futures Markets 21, 1003-1028.

Fama, E.F., French, K.R., 1993. Common risk factors in returns on stocks and bonds. J. Financ. Econ. 33, 3-56.

Fama, E., French, K., 1992. The cross section of expected stock returns. J. Finance 47 427-465.

Fama, E., French, K., 1995. Size and book-to-market factors in earnings and returns. J. Finance $50,131-155$
Fama, E., French, K., 1996. Multifactor explanations of asset pricing anomalies. J Finance $51,55-84$.

Fama, E., MacBeth, J., 1973. Risk, return, and equilibrium: empirical tests. J. Polit. Econ. 81, 607-636.

Frazzini, A., Lamont, 0., 2008. Dumb money: mutual fund flows and the cross sec tion of stock returns. ]. Financ. Econ. 88, 299-322.

Fung, W.H., Hsieh, D.A., 1997. Empirical characteristics of dynamic trading strategies: the case of hedge funds. Rev. Financ. Studies 10, 275-302.

Fung, W.H., Hsieh, D.A., 2000. Performance characteristics of hedge funds and CTA funds: natural versus spurious biases. J. Financ. Quant. Anal. 35, 291-307.

Fung, W.H., Hsieh, D.A., 2001. The risk in hedge fund strategies: theory and evidence from trend followers. Rev. Financ. Studies 14, 313-341.

Fung, W.H.. Hsieh. D.A., 2004. Hedge fund benchmarks: a risk-based approach. Financial Anal. J. 60, 65-80.

Fung, W.H.. Hsieh, D.A., Naik, N.Y., Ramadorai, T., 2008. Hedge funds: performance, risk, and capital formation. J. Finance 63, 1777-1803.

Griffin, J.M., Xu, J., 2009. How smart are the smart guys? A Unique view from hedge fund stock holdings. Rev. Financ. Stud. 22, 2331-2370.

Itzhak, B.D., Franzoni, F., Landier, A., Moussawi, R., 2013. Do hedge funds manipulate stock prices? J. Finance $68,2383-2434$.

Jagannathan, R., Malakhov, A., Novikov, D., 2010. Do hot hands exist among hedge fund managers? An empirical evaluation. J. Finance 65, 217-255.

Jiang, $H ., 2010$. Institutional investors, intangible information, and the book-to-market effect. J. Financ. Econ. 96, 98-126.

Jiao, Y., Ye, P., 2014. Mutual fund herding in response to hedge fund herding and the impacts on stock prices. J. Bank. Finance 49, 131-148.

Joenvaara, ]., Kahra, H., 2017. Hedge Fund Portfolio Selection with Fund Characteristics Working paper.

Jones, C.M., Kaul, G., Lipson, M.L, 1994. Transactions, volume, and volatility. Rev Financ. Stud. 7, 631-651.

Kang, N., Kondor, P., Sadka, R., 2015. Do hedge funds reduce idiosyncratic risk? J. Financ. Quant. Anal. 49, 843-877.

Khan, M., Kogan, L., Serafeim, G., 2012. Mutual fund trading pressure: firm level stock price impact and timing of SEOs. J. Finance 67, 1371-1395.

Kokkonen, J., Suominen, M., 2015. Hedge funds and stock market efficiency. Manag. Sci. 61, 2890-2904.

La Porta, R., Lakonishok, J., Shleifer, A., Vishny, R., 1997. Good news for value stocks: further evidence on market efficiency. J. Finance 52, 859-874.

Miller, E.M., 1977. Risk, uncertainty, and divergence of opinion. J. Finance 32 $1151-1168$.

Mohanram, P.S., 2005. Separating winners from losers among low book-to-market stocks using financial statement analysis. Rev. Account. Stud. 10, 133-170.

Nagel, S., 2005. Short sales, institutional investors, and the cross section of stock returns. J. Financ. Econ. 78, 277-309.

Newey, W. West, K., 1987. A simple positive semi-definite, heteroskedasticity and autocorrelation consistent covariance matrix. Econometrica 55, 703-708.

Patton, A.J., Ramadorai, T., 2013. On the high-frequency dynamics of hedge fund risk exposures. J. Finance 68, 597-635.

Sias, R., 2004. Institutional Herding. Rev. Financ. Stud. 17, 165-206.

Sias, R., Starks, L.T., Titman, S., 2006. Changes in institutional ownership and stock returns: assessment and methodology. J. Business 79, 2869-2910.

Sias, R., Turtle, H.J., Zykaj, B., 2015. Hedge fund crowds and mispricing. Manag. Sci. $62,764-784$.

Sun, Z., Wang, A., Zheng, L., 2012. The road less traveled: strategy distinctiveness and hedge fund performance. Rev. Financ. Stud. 25, 96-143.

Titman, S., Tiu, C., 2011. Do the best hedge funds hedge? Rev. Financ. Stud. 24, $123-168$.

Wermers, R., 1999. Mutual fund herding and the impact on stock prices. J. Finance 54, 581-622.

Yan, X., Zhang, Z., 2009. Institutional investors and equity returns: Are short-term institutions better informed? Rev. Financ. Stud. 22, 893-924. 